\title{
An annotated list of fish parasites (Isopoda, Copepoda, Monogenea, Digenea, Cestoda, Nematoda) collected from Snappers and Bream (Lutjanidae, Nemipteridae, Caesionidae) in New Caledonia confirms high parasite biodiversity on coral reef fish
}

Jean-Lou Justine ${ }^{1 *}$, lan Beveridge ${ }^{2}$, Geoffrey A Boxshall ${ }^{3}$, Rodney A Bray ${ }^{3}$, Terrence L Miller ${ }^{4}$, František Moravec ${ }^{5}$, Jean-Paul Trilles ${ }^{6}$ and lan D Whittington ${ }^{7}$

\begin{abstract}
Background: Coral reefs are areas of maximum biodiversity, but the parasites of coral reef fishes, and especially their species richness, are not well known. Over an 8-year period, parasites were collected from 24 species of Lutjanidae, Nemipteridae and Caesionidae off New Caledonia, South Pacific.

Results: Host-parasite and parasite-host lists are provided, with a total of 207 host-parasite combinations and 58 parasite species identified at the species level, with 27 new host records. Results are presented for isopods, copepods, monogeneans, digeneans, cestodes and nematodes. When results are restricted to well-sampled reef fish species (sample size > 30), the number of host-parasite combinations is 20-25 per fish species, and the number of parasites identified at the species level is 9-13 per fish species. Lutjanids include reef-associated fish and deeper sea fish from the outer slopes of the coral reef: fish from both milieus were compared. Surprisingly, parasite biodiversity was higher in deeper sea fish than in reef fish (host-parasite combinations: 12.50 vs 10.13, number of species per fish 3.75 vs 3.00); however, we identified four biases which diminish the validity of this comparison. Finally, these results and previously published results allow us to propose a generalization of parasite biodiversity for four major families of reef-associated fishes (Lutjanidae, Nemipteridae, Serranidae and Lethrinidae): well-sampled fish have a mean of 20 host-parasite combinations per fish species, and the number of parasites identified at the species level is 10 per fish species.
\end{abstract}

Conclusions: Since all precautions have been taken to minimize taxon numbers, it is safe to affirm than the number of fish parasites is at least ten times the number of fish species in coral reefs, for species of similar size or larger than the species in the four families studied; this is a major improvement to our estimate of biodiversity in coral reefs. Our results suggest that extinction of a coral reef fish species would eventually result in the coextinction of at least ten species of parasites.

Keywords: Biodiversity, Coral reefs, Parasites, Coextinction, Lutjanidae, New Caledonia, South Pacific

\footnotetext{
*Correspondence: justine@mnhn.fr

'UMR 7138 Systématique, Adaptation, Évolution, Muséum National d'Histoire Naturelle, Case postale 51, 55, rue Buffon, 75231 Paris cedex 05, France

Full list of author information is available at the end of the article
} 


\section{Background}

Parasites probably constitute the least known component of biodiversity in coral reefs, which are considered some of the most diverse ecosystems on the planet [1]. An early evaluation of parasite biodiversity of fish of the Great Barrier Reef (GBR) in Australia proposed a number of 20,000 parasites (all groups included) in the 1,000 fish species believed to exist in the area at this time; however, this evaluation, published as short papers [2,3] was based on very limited data. More reliable estimates are available for only two groups, the digeneans and monogeneans. Estimates were 2,270 digenean species in the 1,300 fish species of the GBR [4] and 2,000 monogenean species on the 1,000 fish species recorded around Heron Island, in the southern GBR [5].

An eight-year program allowed us to investigate the biodiversity of fish parasites off New Caledonia (South Pacific), the largest coral lagoon of the world. A compilation of available literature including a number of papers produced by this program [6] concluded that only $2 \%$ of fish parasite biodiversity was known in New Caledonia. Two subsequent comprehensive papers provided abundant, previously unpublished data and a compilation of already published information on two families of fish, the Serranidae (groupers) and the Lethrinidae (emperors) $[7,8]$. In this paper, we provide information about the parasites of the Lutjanidae, Nemipteridae and Caesionidae and compare our results with those already published for the other families.

\section{Results}

Results are presented as a host-parasite list (Appendix 1), a parasite-host list (Appendix 2) and a list of material deposited (Appendix 3). The number of host-parasite combinations (HPCs) and the number of species-level identified parasite - host-parasite combinations (SLIPHPCs) found in each fish species are given in Table 1.

\section{Discussion}

\section{Comments on each group}

For brevity, in this section references to our own published papers on these fish families (available in Table 2 and Appendix 2) are kept to a minimum. For parasites, the "minimized number of taxa" is a cautious minimized evaluation in which all unidentified taxa in a group are counted as a single taxon [8].

\section{Fish}

In this paper, we group results from three families of fish, namely the Lutjanidae, Nemipteridae and Caesionidae. Clearly, most of the results concern the Lutjanidae but we included the two other families because they are closely related [9-11]. Modern molecular phylogenies are available for the Lutjanidae [12-15] and confirm the close relationship of the Lutjanidae and Caesionidae.

According to the most recent survey [16], the Lutjanidae, Caesionidae and Nemipteridae include, respectively, 17, 4, and 5 genera and 108, 22 and 66 species, with a total of 26 genera, 196 species. The numbers of species in New Caledonia [17] are, respectively, 43, 13, and 16, with a total 72 species. In this work, we report parasitological results from 18 lutjanid species, 1 caesionid and 6 nemipterids; the total, 25 species, represents 34\% of the species reported from New Caledonia, and 13\% of the world number of species for the three families.

Diets of lutjanids and nemipterids off New Caledonia mainly comprise fish, crustaceans and occasionally molluscs [18], all of which can serve as intermediate hosts for parasites such as nematodes, digeneans and cestodes.

Most fishes included in this study are reef-dwelling; however, we also include several lutjanids (two species of Etelis and three species of Pristipomoides) which are deeper water fishes, collected from the outer slope of the barrier reef of New Caledonia [19]. These fishes provide data for a comparison of the parasitic fauna of coral-associated and deeper sea fishes.

As occurs often in the South Pacific, parasitologists have had to face problems with fish taxonomy [8,20-23]. Pentapodus aureofasciatus Russell, 2001, was first identified as Pentapodus sp. in the description of a nematode [24] but this was corrected later [25].

\section{Isopoda}

Adult isopods were rare and belonged to three families: Aegidae, Corallanidae and Cymothoidae. The single aegid, Aega musorstom, was found on a deep water lutjanid. Two cymothoids (Anilocra gigantea and An. longicauda) were found only on deep water lutjanids, but the single corallanid, Argathona macronema, was found on a coral dwelling lutjanid.

An. gigantea was already known from New Caledonia and was recorded from the branchial region of the deep water lutjanid Etelis carbunculus off "Banc de la Torche, au sud-est de la Nouvelle Calédonie" [26]. It was also recorded from the Pacific Ocean from the gills of Epinephelus sp. and Pr. flavipinnis, off Suva reefs, Suva, Fiji [27] and from the Indian Ocean from an unidentified host [28-30]. We found this species again on Et. carbunculus, but Et. coruscans and Pr. filamentosus are new host records. Interestingly, we did not collect this species from the branchial region or from the gills of the host fish, as reported by previous authors but on the anterior part of the body just behind the head. A female specimen of An. gigantea attached behind the head of Pr. filamentosus is illustrated by a colour photograph (Figure 1).

An. longicauda was already known from the Indian and the Pacific Oceans [30]. It was previously recorded 
Table 1 Number of host-parasite combinations (HPCs) found in 24 species of caesionids, lutjanids and nemipterids in New Caledonia

\begin{tabular}{|c|c|c|c|c|c|c|c|c|c|c|c|c|c|c|c|}
\hline Family and habitat & Fish species & Total & Gill & Abdo & Isop & Cope & Mono & Poly & Dige & Both & Tetr & Tryp & Nema & Other & Total \\
\hline Caesionidae & Caesio cuning & 8 & 4 & 8 & & & & & $2(0)$ & $1(0)$ & $1(0)$ & & $1(0)$ & & $5(0)$ \\
\hline \multirow{13}{*}{$\begin{array}{l}\text { Lutjanidae, } \\
\text { reef-associated }\end{array}$} & Aprion virescens & 3 & 3 & 3 & & & $1(1)$ & & $2(2)$ & & & & & & $3(3)$ \\
\hline & Lutjanus adetii & 5 & 0 & 5 & & & & & $2(2)$ & $1(0)$ & & & $1(0)$ & & $4(2)$ \\
\hline & Lutjanus argentimaculatus & 4 & 3 & 3 & $1(0)$ & $2(1)$ & $5(3)$ & & $4(4)$ & & $1(0)$ & & & & $13(8)$ \\
\hline & Lutjanus fulviflamma & 17 & 11 & 11 & & $2(1)$ & $3(2)$ & $1(0)$ & $2(2)$ & & & & $1(0)$ & & $9(5)$ \\
\hline & Lutjanus fulvus * & 2 & 1 & 0 & & & $4(2)$ & & & & & & & & $4(2)$ \\
\hline & Lutjanus gibbus * & 2 & 2 & 1 & & $1(1)$ & $1(0)$ & & & & & & & & $2(1)$ \\
\hline & Lutjanus kasmira & 16 & 12 & 12 & & $1(0)$ & $6(0)$ & & $5(2)$ & $1(0)$ & $1(0)$ & & $1(0)$ & & $15(2)$ \\
\hline & Lutjanus monostigma* & 0 & 0 & 0 & $1(1)$ & & & & & & & & & & $1(1)$ \\
\hline & Lutjanus quinquelineatus & 12 & 0 & 6 & & & $5(3)$ & & $2(2)$ & & $1(0)$ & & $1(0)$ & & $9(5)$ \\
\hline & Lutjanus rivulatus * & 2 & 2 & 2 & & & $1(0)$ & & & & & & $1(0)$ & $1(0)$ & $3(0)$ \\
\hline & Lutjanus russellii & 6 & 0 & 1 & $1(0)$ & & $4(2)$ & $1(0)$ & $2(1)$ & & & & & & $8(3)$ \\
\hline & Lutjanus vitta & 42 & 19 & 31 & & $1(0)$ & $6(2)$ & & $5(3)$ & & $1(0)$ & $2(2)$ & $5(2)$ & & 20(9) \\
\hline & Macolor niger * & 2 & 2 & 1 & & $3(1)$ & $2(0)$ & & $1(0)$ & & & & & & $6(1)$ \\
\hline \multirow{5}{*}{$\begin{array}{l}\text { Lutjanidae, } \\
\text { deep-sea }\end{array}$} & Etelis carbunculus & 16 & 5 & 3 & $1(1)$ & $4(1)$ & $1(1)$ & & $3(2)$ & & $1(0)$ & $1(0)$ & $2(1)$ & $1(0)$ & $14(6)$ \\
\hline & Etelis coruscans & 18 & 11 & 5 & $1(1)$ & $4(1)$ & $2(2)$ & $1(0)$ & $3(1)$ & & & $1(0)$ & $2(2)$ & & $14(7)$ \\
\hline & $\begin{array}{l}\text { Pristipomoides } \\
\text { argyrogrammicus }\end{array}$ & 20 & 14 & 18 & $1(1)$ & $1(0)$ & $3(1)$ & & $4(3)$ & & $1(0)$ & $1(0)$ & $2(1)$ & & $13(6)$ \\
\hline & Pristipomoides auricilla* & 2 & 2 & 2 & $1(0)$ & & $1(0)$ & & $1(1)$ & & $1(0)$ & $1(0)$ & $3(1)$ & & $8(2)$ \\
\hline & Pristipomoides filamentosus & 7 & 2 & 2 & $2(2)$ & $1(1)$ & $1(0)$ & & $2(0)$ & & & & $3(2)$ & & $9(5)$ \\
\hline \multirow[t]{11}{*}{ Nemipteridae } & Nemipterus furcosus & 239 & 111 & 160 & $1(0)$ & & $2(0)$ & $1(0)$ & $5(4)$ & $1(0)$ & $1(0)$ & $6(6)$ & $7(3)$ & $1(0)$ & 25(13) \\
\hline & Pentapodus aureofasciatus & 23 & 19 & 12 & $1(0)$ & $1(0)$ & $2(1)$ & $1(0)$ & $4(0)$ & & $1(0)$ & & $2(0)$ & & $12(1)$ \\
\hline & Pentapodus nagasakiensis * & 2 & 2 & 2 & & & & & $2(0)$ & & $1(0)$ & & $1(0)$ & & $4(0)$ \\
\hline & Scolopsis bilineata & 12 & 8 & 9 & $1(0)$ & & & & $2(1)$ & & & & $1(0)$ & $1(0)$ & $5(1)$ \\
\hline & Scolopsis taenioptera ${ }^{*}$ & 3 & 2 & 3 & & & & & & & & & $1(0)$ & & $1(0)$ \\
\hline & $\begin{array}{l}\text { Total Caesionidae } \\
\text { (1 species) }\end{array}$ & 8 & 4 & 8 & & & & & $2(0)$ & $1(0)$ & $1(0)$ & & $1(0)$ & & $5(0)$ \\
\hline & $\begin{array}{l}\text { Partial total Lutjanidae, } \\
\text { reef (13) }\end{array}$ & 113 & 55 & 76 & $3(1)$ & $10(4)$ & $38(15)$ & $2(0)$ & $25(18)$ & $2(0)$ & $4(0)$ & $2(2)$ & $10(2)$ & $1(0)$ & $97(42)$ \\
\hline & $\begin{array}{l}\text { Partial total Lutjanidae, } \\
\text { deep-sea (5) }\end{array}$ & 63 & 34 & 30 & $6(5)$ & $10(3)$ & $8(4)$ & $1(0)$ & $13(7)$ & $0(0)$ & $3(0)$ & $4(0)$ & $12(6)$ & $1(0)$ & $58(25)$ \\
\hline & $\begin{array}{l}\text { Total Lutjanidae } \\
\text { (18 species) }\end{array}$ & 176 & 89 & 106 & $9(6)$ & $20(7)$ & $46(19)$ & $3(0)$ & $38(25)$ & $2(0)$ & $7(0)$ & $6(2)$ & $22(8)$ & $2(0)$ & $155(67)$ \\
\hline & $\begin{array}{l}\text { Total Nemipteridae } \\
\text { (5 species) }\end{array}$ & 279 & 142 & 186 & $3(0)$ & $1(0)$ & $4(1)$ & $2(0)$ & $13(5)$ & $1(0)$ & $3(0)$ & $6(6)$ & 12(3) & $2(0)$ & $47(15)$ \\
\hline & Total (24 species) & 463 & 235 & 300 & $12(6)$ & $21(7)$ & $50(20)$ & $5(0)$ & $53(30)$ & $4(0)$ & $11(0)$ & $12(8)$ & $35(11)$ & $4(0)$ & 207(82) \\
\hline
\end{tabular}

*: species with low sample size or only anecdotal collections, excluded from general calculations in Table 3. For each number: HPCs (SLIP-HPCs) i.e. number of host-parasite combinations, and, within parentheses, number of species level identified parasite - host-parasite combinations.

from Swains Reefs, Great Barrier Reef, Marion Reef, Australian Coral Sea, North West Shelf of Western Australia, Krakatua, Indonesia [31], Singapore and Poulo Condor, Vietnam [29,31], Ragay Gulf, Pasacao and Maribuyoc Bay, Bohol Island, Philippines [27]. This species has been reported from Plectorhynchus goldmani, Diagramma picta and Priacanthus sp. [31]. Pr. argyrogrammicus is a new host record and New Caledonia is a new geographical record.
Aega musorstom was already known from New Caledonia, in the vicinity of Western New Caledonia including the Coral Sea region of the Chesterfield Archipelago and the Loyalty Islands, at depths from 475 to $615 \mathrm{~m}$ [32]. Only one fish association was noted, "Synagonopi sp. 1" probably a species of Synagrops (Acropomatidae) [32]. Pr. filamentosus is a new host record.

Argathona macronema was already known from New Caledonia [7,33]. It was previously reported from 
Table $\mathbf{2}$ List of $\mathbf{5 8}$ species identified at the species level with Latin binomial, with full authorities

Isopoda (4)
Aegidae: Aega musorstom Bruce, 2004

Corallanidae: Argathona macronema (Bleeker, 1857) Monod, 1933

Cymothoidae: Anilocra gigantea (Herklots, 1870) Schiœedte \& Meinert, 1881

Cymothoidae: Anilocra longicauda Schiœedte \& Meinert, 1881

Caligidae: Caligus brevis Shiino, 1954

Dissonidae: Dissonus excavatus Boxshall, Lin, Ho, Ohtsuka, Venmathi Maran \& Justine, 2008

Hatschekiidae: Hatschekia clava Kabata, 1991

Hatschekiidae: Hatschekia tanysoma Ho \& Kim, 2001

Lernaeopodidae: Parabrachiella lutiani (Pillai, 1968)

Pennellidae: Lernaeolophus sultanus (H Milne Edwards, 1840) Heller, 1865

Monopisthocotylea (11)

Ancyrocephalidae: Haliotrematoides lanx Kritsky \& Justine, 2009 in Kritsky, Yang \& Sun, 2009

Ancyrocephalidae: Haliotrematoides longitubocirrus (Bychowsky \& Nagibina, 1971) Kritsky, Yang \& Sun, 2009

Ancyrocephalidae: Haliotrematoides novaecaledoniae Kritsky \& Justine, 2009 in Kritsky, Yang \& Sun, 2009

Ancyrocephalidae: Haliotrematoides patellacirrus (Bychowsky \& Nagibina, 1971) Kritsky, Yang \& Sun, 2009

Ancyrocephalidae: Haliotrematoides potens Kritsky \& Justine, 2009 in Kritsky, Yang \& Sun, 2009

Ancyrocephalidae: Haliotrematoides tainophallus Kritsky \& Justine, 2009 in Kritsky, Yang \& Sun, 2009

Capsalidae: Benedenia elongata (Yamaguti, 1968) Egorova, 1997

Capsalidae: Lagenivaginopseudobenedenia etelis Yamaguti, 1966

Capsalidae: Pseudonitzschia uku Yamaguti, 1965

Capsalidae: Trilobiodiscus lutiani Bychowsky \& Nagibina, 1967

Diplectanidae: Calydiscoides limae Justine \& Brena, 2009

Digenea (21)

Acanthocolpidae: Pleorchis uku Yamaguti, 1970

Acanthocolpidae: Stephanostomum uku Yamaguti, 1970

Cryptogonimidae: Adlardia novaecaledoniae Miller, Bray, Goiran, Justine \& Cribb, 2009

Cryptogonimidae: Euryakaina manilensis (Velasquez, 1961) Miller, Adlard, Bray, Justine, \& Cribb, 2010

Cryptogonimidae: Euryakaina marina (Hafeezullah \& Siddiqi, 1970) Miller, Adlard, Bray, Justine, \& Cribb, 2010

Cryptogonimidae: Metadena rooseveltiae (Yamaguti, 1970) Miller \& Cribb, 2008

Cryptogonimidae: Retrovarium manteri Miller \& Cribb, 2007

Cryptogonimidae: Retrovarium saccatum (Manter, 1963) Miller \& Cribb, 2007

Cryptogonimidae: Siphoderina hirastricta (Manter, 1963) Miller \& Cribb, 2008

Cryptogonimidae: Siphoderina ulaula (Yamaguti, 1970) Miller \& Cribb, 2008

Cryptogonimidae: Varialvus charadrus Miller, Bray, Justine \& Cribb, 2010

Fellodistomatidae: Tergestia magna Korotaeva, 1972

Hemiuridae: Ectenurus trachuri (Yamaguti, 1934) Yamaguti, 1970

Lepocreadiidae: Lepidapedoides kalikali Yamaguti, 1970

Monorchiidae: Allobacciger macrorchis Hafeezullah \& Siddiqi, 1970

Opecoelidae: Hamacreadium mutabile Linton, 1910

Opecoelidae: Macvicaria jagannathi (Gupta \& Singh, 1985) Bijukumar, 1997

Opecoelidae: Neolebouria blatta Bray \& Justine, 2009

Opecoelidae: Neolebouria lineatus Aken'Ova \& Cribb, 2001

Sclerodistomidae: Prosogonotrema bilabiatum Vigueras, 1940

Transversotrematidae: Transversotrema borboleta Hunter \& Cribb, 2012

Lacistorhynchidae: Callitetrarhynchus gracilis (Rudolphi, 1819) Pintner, 1931

Lacistorhynchidae: Floriceps minacanthus Campbell et Beveridge, 1987

Lacistorhynchidae: Pseudolacistorhynchus heroniensis (Sakanari, 1989) Palm, 2004

Otobothriidae: Otobothrium mugilis Hiscock, 1954

Tentaculariidae: Nybelinia goreensis Dollfus, 1960

Tentaculariidae: Nybelinia indica Chandra, 1986 
Table 2 List of 58 species identified at the species level with Latin binomial, with full authorities (Continued)

\begin{tabular}{ll}
\hline Nematoda (9) & Tentaculariidae: Nybelinia queenslandensis Jones \& Beveridge, 1998 \\
\hline & $\frac{\text { Anisakidae: Raphidascaris (Ichthyascaris) etelidis Moravec \& Justine, } 2012}{\text { Camallanidae: Camallanus carangis Olsen, } 1952}$ \\
\hline & $\frac{\text { Capillariidae: Pseudocapillaria novaecaledoniensis Moravec \& Justine, } 2010}{\text { Cucullanidae: Cucullanus bourdini Petter \& Le Bel, } 1992}$ \\
\hline & $\frac{\text { Philometridae: Philometra brevicollis Moravec \& Justine, } 2011}{\text { Prichometridae: Philometra mira Moravec \& Justine, } 2011}$ \\
\hline
\end{tabular}

This Table shows all binomial names of parasite taxa collected (SLIPs); since several names are extremely long, its main purpose is to lighten the other tables and the text. Authors involved in the description and combination of taxa for Isopoda: $[28,29,32,167,168]$; for Copepoda: [36,37,155,169-172]; for Monopisthocotylea: [45,49,66,67,156,173-175]; for Digenea: [71-74,76,77,79,84,86,87,89,97,176-180]; for Trypanorhyncha: [99,181-188]; for Nematoda: [24,157-161,189,190].

Epinephelus tauvina, Diagramma cinerascens, Pseudolabrus sp., Trachichtodes affinis, Cromileptes altivelis, $\mathrm{Lu}$. argentimaculatus, Plectropomus leopardus and Pl. maculatus [33]. It was found again later on Pl. leopardus and in addition on Pl. laevis [7]. Lu. monostigma is a new host record.

Larval isopods belonged to the Gnathiidae. Gnathiids, found as praniza larvae, were collected on 6 species of nemipterids and lutjanids (5 reef-dwelling, 1 deep water). In New Caledonia, larval gnathiids were found on most fish families examined (serranids, lethrinids, lutjanids, nemipterids and many others). Adult isopods were found on serranids and lutjanids but not on lethrinids and nemipterids $[7,8]$. The biodiversity of larval gnathiids is hard to evaluate $[34,35]$, but it is likely that several species are involved.

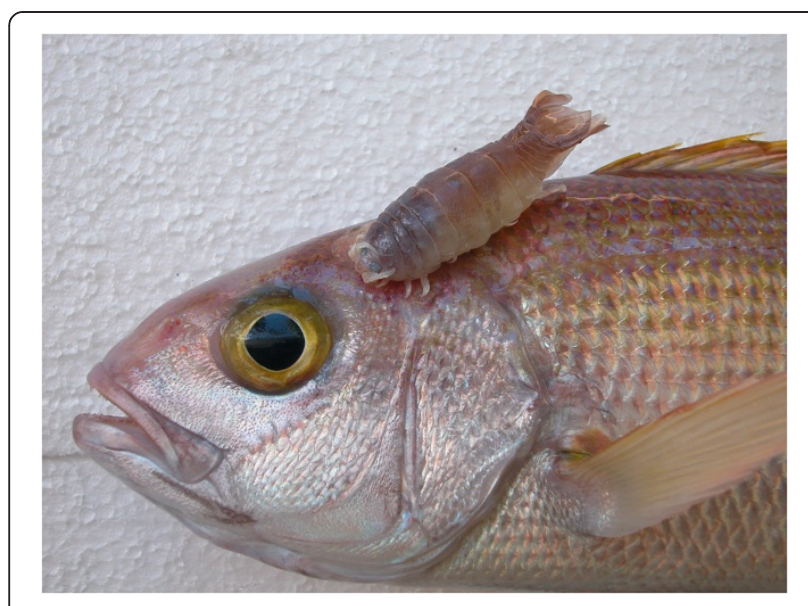

Figure 1 Anilocra gigantea (Isopoda, Cymothoidae), specimen MNHN Is6292, on the deep-sea lutjanid Pristipomoides filamentosus.

\section{Copepoda}

Fourteen taxa, including 6 identified at the species level, were found. Seven species of Hatschekia were distinguished but only two are known species, the other five (Figure 2) are not formally described. A total of 21 undescribed Hatschekia species has now been listed from New Caledonian fish ([7,8]; this paper). Hatschekia tanysoma was originally described from Kuwait Bay, from Lu. fulviflamma [36] and is reported here from the Pacific for the first time, but from the same host. In contrast H. clava was described from Heron Island from material collected from Lu. carponotatus (Richardson) (as Lu. chrysotaenia) [37].

The copepods belonged to five families, namely Caligidae, Dissonidae, Hatschekiidae, Lernaeopodidae and Pennellidae. Larvae and premetamorphic adults belonging to the Pennellidae were found on the deep-sea lutjanid Et. coruscans. The only adult member of this family found during eight years of sampling was a single female of Lernaeolophus sultanus (Figure 3) found on Pr. filamentosus. Pennellids are known to utilise two different hosts during their life cycle, either two different fish hosts or a pelagic mollusc and a final fish host [38]. However, the life cycle of no Lernaeolophus species has ever been elucidated so it is not possible to confirm whether the developmental stages found on Pr. filamentosus are those of L. sultanus. L. sultanus exhibits the lowest host specificity of any copepod parasite, occurring on 16 different host fishes in the Mediterranean [39].

Caligus brevis is reported here from two species of Etelis, Et. carbunculus and Et. coruscans, for the first time. This species was previously reported only from labrid hosts in Japanese [40] and New Zealand waters [41]. Ho \& Lin (2004) suspected that C. brevis might be synonym of Caligus oviceps Shiino, 1952, but refrained from synonymizing them [42]. C. oviceps has already been reported from a lethrinid host (Lethrinus haematopterus 


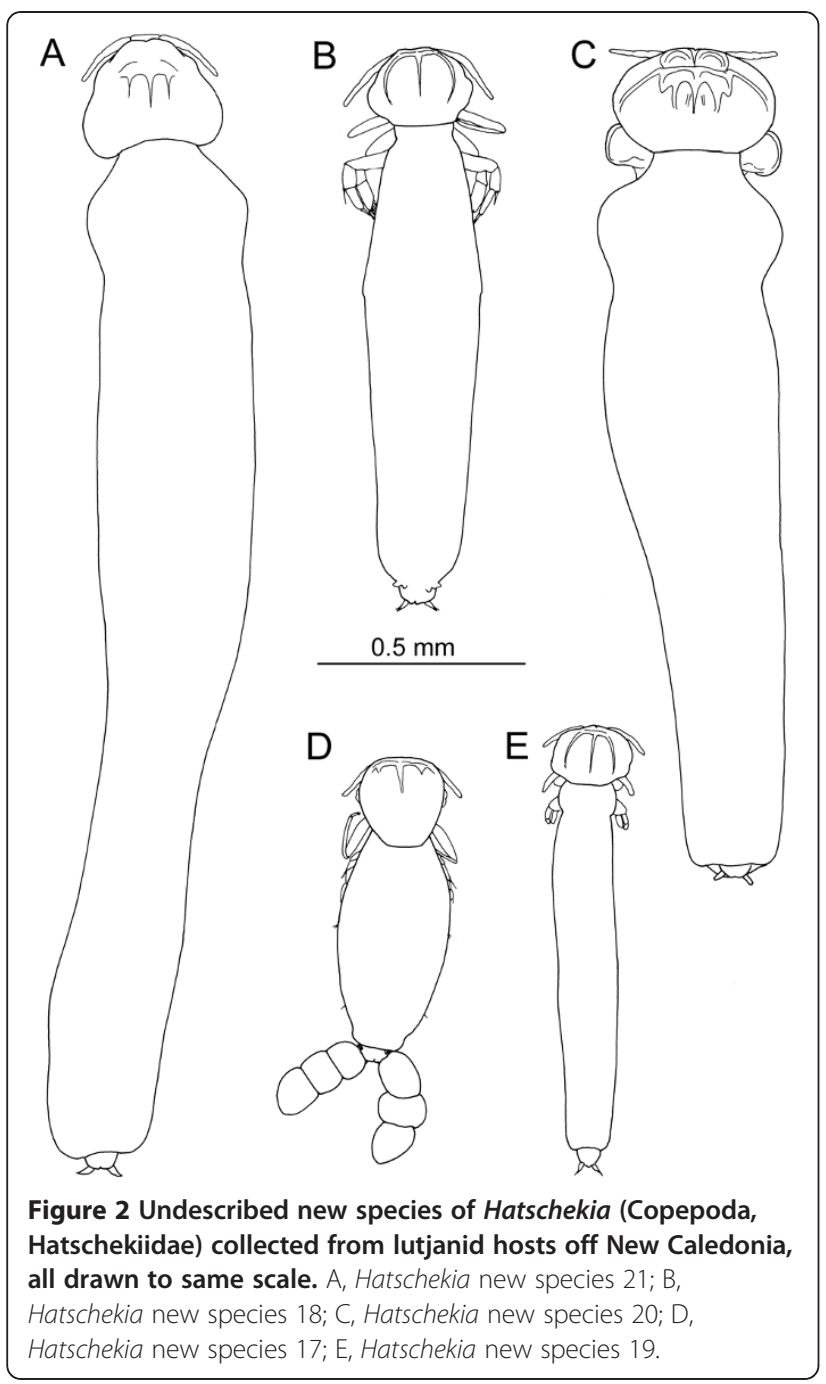

Temminck \& Schlegel) but it has a broad range of hosts including species of Cheilodactylidae, Kyphosidae, Monacanthidae, Mullidae, Scaridae, and Siganidae [42].

All the copepods are from the gills; none was found on the skin. Insufficient sampling precludes interpretation of the absence of copepods from several of the fish species listed here; however, the absence of copepods on fork-tailed threadfin breams, Ne. furcosus, with 239 specimens examined at various seasons during eight years is certainly significant.

\section{Monogenea}

The minimized number of taxa for polyopisthocotyleans was 2 and for monopisthocotyleans was 23 .

Polyopisthocotyleans were represented by Allomicrocotyla sp. on the deep-sea lutjanid Et. coruscans, and several records of unidentified microcotylids or other polyopisthocotylean families from coral-associated lutjanids and nemipterids. Polyopisthocotyleans on reef lutjanids were rare; similarly, polyopisthocotyleans were rare on Lu. griseus in the Gulf of Mexico [43]. The rarity of polyopisthocotyleans from 4 species of lutjanids off Heron Island on the Great Barrier Reef is apparent from the literature [44] and from unpublished observations by I.D. Whittington at the same locality.

Monopisthocotyleans included four families, the Ancyrocephalidae, Capsalidae, Diplectanidae and Gyrodactylidae.

Ancyrocephalids included a series of species of the recently described genus Haliotrematoides Kritsky, Yang \& Sun, 2009, several species of Euryhaliotrema Kritsky \& Boeger, 2002, which are still undescribed, and we also have records of various ancyrocephalids not attributed to a genus. Clearly, the lutjanids harbour an impressive ancyrocephalid radiation, with probably several species

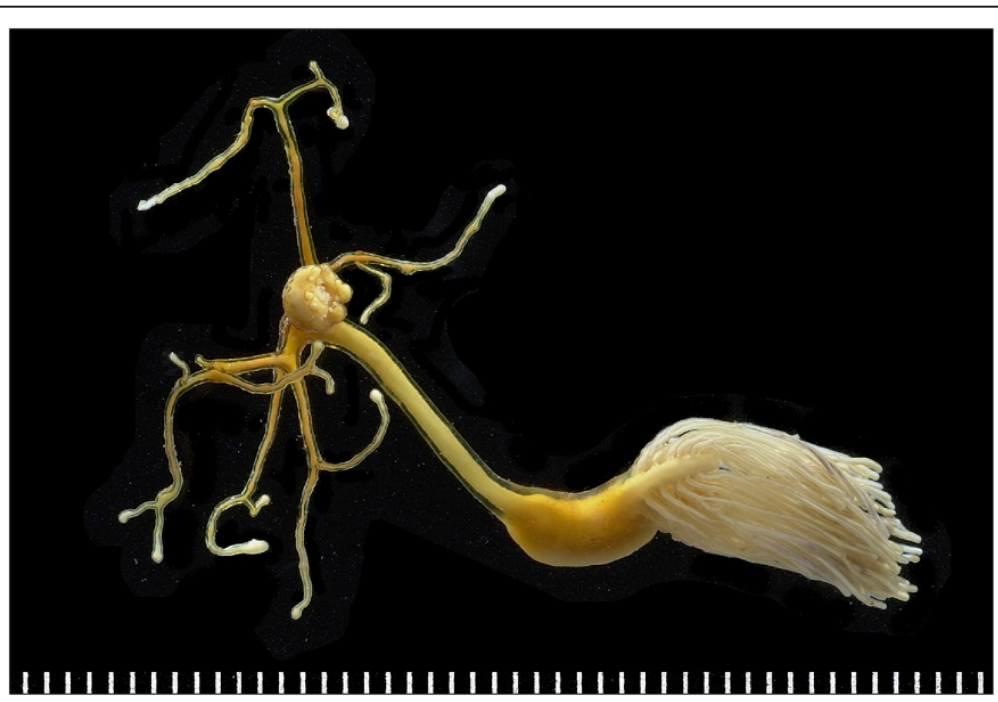

Figure 3 Lernaeolophus sultanus (Copepoda, Pennellidae), specimen BMNH 2010.750, from Pristipomoides filamentosus off New Caledonia. Scale, each scale division $=1 \mathrm{~mm}$. 
on each fish species; some of these species seem to be strictly species-specific, others are found on up to 5 different host species [45]. These ancyrocephalids might be a threat for cultured snappers [46].

Diplectanids included several species of Diplectanum and one species of Calydiscoides. Calydiscoides species are numerous in lethrinids [8]; only one species was found in New Caledonia in the families studied here, in the nemipterid Pentapodus aureofasciatus, but none in members of Scolopsis and Nemipterus, which are known to harbour sometimes numerous species of Calydiscoides in other localities $[44,47,48]$.

Four species are attributed here to Diplectanum. D. opakapaka Yamaguti, 1968 was described from $\operatorname{Pr}$. microlepis and Aphareus rutilans off Hawaii [49] and D. curvivagina Yamaguti, 1968 was described from Pr. sieboldii and Pr. auricilla off Hawaii [49] and have rarely been recorded since [50]. D. fusiformis Oliver \& Paperna, 1984, described from Lu. kasmira off Kenya [51] was recorded again from its type-host and Lu. fulvus in French Polynesia and Hawaii [52,53]. D. spirale Nagibina, 1976 described from Lu. fulviflamma [54] has apparently not been recorded since its original description. In the absence of a comparative examination of the type specimens, we prefer to keep our identifications of these four species as "cf." and we do not comment on their generic attribution.

Gyrodactylids were represented by a single specimen found on Macolor niger, which is a relatively difficult fish to catch and unfortunately additional specimens could not be obtained. It is the first gyrodactylid collected from a lutjanid. It should be noted that several coralassociated lutjanids were soaked for collection of skin monogeneans such as capsalids and digeneans such as transversotrematids, but no other gyrodactylid specimens were recovered.

Capsalid systematics is currently under reinvestigation (e.g. [55-57]) after Perkins et al. [58] demonstrated that the current morphological classification has limited congruence with a phylogenetic hypothesis based on three unlinked nuclear genes. Apparently homoplastic morphological features were highlighted throughout the molecular phylogeny [58]. This has entailed a reluctance to assign some taxa to genera until appropriate characters and generic and subfamilial definitions are better refined within a phylogenetic context. Hence 'identifications' of four taxa are herein provided only as Capsalidae sp. 6, 7, 13 and 17, differentiated phylogenetically by Perkins [59] using nuclear and mitochondrial markers, but from morphological 'identifications' made by I.D. Whittington.

Of the Capsalidae we report here, four from the gills were identified to species (Benedenia elongata from three lutjanid species; Lagenivaginopseudobenedenia etelis from Et. coruscans; Pseudonitzschia uku from Aprion virescens; Trilobiodiscus lutiani from Lu. argentimaculatus). Two capsalid species recovered from gills of Macolor niger and Ne. furcosus remained unidentified. A species assigned only as a Metabenedeniella sp. was recovered from the pectoral fins (see [59]; probably a new species, I.D. Whittington unpublished) and the four capsalid species assigned only as Capsalidae sp. 6, 7, 13 and 17 [59] were recovered from the gills, fins, body washings, branchiostegal membranes and the head of their hosts (for details, see Appendix 1). Additional external sites, rarely examined in this study, received careful scrutiny only when I.D. Whittington visited Nouméa in October/November 2008. During his visit, thorough fish necropsies (four specimens of Lu. vitta; six specimens of Ne. furcosus; one specimen of Lu. kasmira [which was totally uninfected by capsalids]; two specimens of Pr. argyrogrammicus; one specimen of $\mathrm{Lu}$. argentimaculatus) paid particular attention to external microhabitats known to support capsalids (e.g. [60]) followed by freshwater bathing of the same tissues to ensure recovery of parasites that may be cryptic due to camouflage or transparency (e.g. [61]). Dissections of fish at other times, when microhabitats other than gills that may harbour capsalids remained unstudied, seem likely to have appreciably underestimated the diversity of capsalid monogeneans from the caesionids, lutjanids and nemipterids examined.

Other factors in this study that contributed to an inability to assign capsalids to genera from gills, pelvic, pectoral and anal fins, body washings, branchiostegal membranes and head included small numbers of specimens recovered and the juvenile status of many capsalid individuals from Ne. furcosus. Adult specimens of B. lutjani from $L u$. carponotatus from Heron Island on the Great Barrier Reef preferentially inhabit the branchiostegal membranes, and the pelvic fins was the site where protandrous parasites that possess a vagina may become inseminated [62,63]. Discovery of juvenile specimens of Capsalidae sp. 13 on pelvic and anal fins and branchiostegal membranes and small, recently matured adults on the branchiostegal membranes of Ne. furcosus suggests a similar migration and habitat partitioning for this taxon on the nemipterid.

Several of the capsalids reported in this study represent new records. Metabenedeniella species are previously reported from oplegnathids, serranids and haemulids [64]. Our report of a Metabenedeniella sp. from a lutjanid (Appendix 1) represents a new fish family and a new geographic record for this capsalid genus. Benedenia elongata was described as Pseudobenedenia elongata from a priacanthid, Priacanthus boops, and two lutjanids, Pr. sieboldii and Arnillo auricilla (now Pr. auricilla, see [65]), off Hawaii [49]. Although two specimens of Pr. auricilla were studied in the present investigation, 
B. elongata was not recorded. It has, however, been recorded from three new host lutjanid species, Et. carbunculus, Et. coruscans and Pr. argyrogrammicus, each of which represents a new host and geographic record for $B$. elongata. Like deep water lutjanids, priacanthids can also occur in deep water and it seems as though $B$. elongata has relatively low host specificity among several deeper water fish species in these two families.

Lagenivaginopseudobenedenia etelis was originally described from Et. carbunculus off Hawaii by Yamaguti [66]. While 16 specimens of Et. carbunculus from New Caledonia were studied, La. etelis was not reported but we did record it from Et. coruscans, a new host and geographic record for this taxon (Appendix 1). As suggested for B. elongata, La. etelis may also exhibit relatively low host specificity and infect several deep-sea lutjanids. Further sampling may indicate whether La. etelis is specific to species of Etelis or whether this capsalid can also infect Pristipomoides species.

As far as we are aware, there have been no published reports of Trilobiodiscus lutiani since its original description [67] although it does occur on the type host, $L u$. argentimaculatus in north Queensland (I.D. Whittington, unpublished). The present report of T. lutiani from New Caledonia is a new geographic record (Appendix 1).

For the same sampling limitations presented above, it is possible that specimens of Anoplodiscidae known from external surfaces of nemipterids on the Great Barrier Reef ([68]; I.D. Whittington, unpublished) may have been overlooked in the present study.

\section{Digenea}

The total minimized number of taxa was 33, with 21 species identified at the species level (SLIPs).

Eleven families were represented: Acanthocolpidae (2 SLIPs), Cryptogonimidae (12 spp, 9 SLIPs), Didymozoidae (2 unidentified adults, unknown number of species as unidentified larvae), Fellodistomatidae (1 SLIP), Hemiuridae (3 spp, 1 SLIP), Lecithasteridae (1 sp.), Lepocreadiidae (1 SLIP), Monorchiidae (1 SLIP), Opecoelidae (8 spp, 4 SLIPs), Sclerodistomidae (1 SLIP) and Transversotrematidae (1 SLIP).

The dominant digenean family is the Cryptogonimidae. Members of this family and of the Acanthocolpidae and the Didymozoidae utilise fishes as second intermediate hosts [69], indicating that this component of the lutjanid (and related families) diet is a major source of its digenean fauna. The other digenean families utilise a wide range of invertebrates, often crustaceans, as second intermediate hosts, and occasionally lepocreadiids and opecoelids also use fishes [69]. Some hemiuroids (e.g. Lecithochirium) have interpolated a third intermediate host, a fish, into their life-cycle [70]. Considering the importance of fishes in the diet and infection of lutjanids it is, perhaps, surprising that we found no members of the common family Bucephalidae, which also utilises fishes as second intermediate hosts.

The cryptogonimids include one species, Adlardia novaecaledoniae, which is known only from New Caledonia [71]. Other identified cryptogonimids are reported more widely, from the Great Barrier Reef (GBR) (Retrovarium manteri), from Fiji ( $R$. saccatum), from both these localities (Siphoderina hirastricta), from Hawaii (Metadena rooseveltiae), from Hawaii and China (S. ulaula) and from the Philippines and the GBR (Euryakaina manilensis) [72-76]. Two species also occur in the Indian Ocean. Varialvus charadrus occurs in the GBR and the Maldives and E. marina is reported from the GBR, the Bay of Bengal and Ningaloo Reef, Western Australia [77-79].

Both acanthocolpid species are reported from Aprion virescens, and are known from the Western Pacific, from Hawaii to the Great Barrier Reef [74,75,80,81].

The Opecoelidae is a difficult group, with many similar species described. Of the four SLIPs one, Hamacreadium mutabile, is a cosmopolitan parasite reported in many lutjanid species in the Atlantic, Indian and Pacific Oceans [82]. This is one of the few opecoelids known to utilise fishes as its second intermediate host [83]. Of the other species, Neolebouria blatta is reported only from New Caledonia, $N$. lineatus only from southern Western Australia, and Macvicaria jagannathi from the Bay of Bengal [84-88].

The Transversotrematidae includes a single species, which could be identified at the species level. Morphologically and biologically this form agrees with the variable species Transversotrema borboleta, reported from chaetodontids and lutjanids (including Lu. kasmira) from the northern and southern GBR [89]. The species includes 3 genotypes which are not partitioned to different host families, but only genotype ' $\mathrm{G} 2$ ' is reported in Lu. kasmira.

Didymozoidae include several records of unidentified juveniles from coral and deep-sea lutjanids and nemipterids; juvenile didymozoids are found in the intestine of most marine tropical fish $[7,8,90,91]$ and the present records are not surprising. Adult didymozoids include a relatively abundant long filiform form found under the scales of the deep water Et. carbunculus.

Two of the other SLIPs are widespread in the Atlantic and Indo-West Pacific Region, i.e., Ectenurus trachuri, Prosogonotrema bilabiatum (see [92,93]). E. trachuri is mostly reported in carangids, but $P$. bilabiatum is a common parasite of lutjanids. Allobacciger macrorchis (also known as Monorcheides macrorchis) is reported mainly in the Indian Ocean, but also Japan [77,94,95]. Lepidapedoides kalikali is known only from Hawaii, Japan and Palau [74,96]. Tergestia magna is reported 
from emmelichthyid fishes from the waters off southern Australia [97].

\section{Cestoda Bothriocephalidea and Tetraphyllidea}

For these two cestode orders, only larvae were found, and species identification is not possible.

Bothriocephalideans were represented by larvae found in four species of fishes. They were especially abundant and highly prevalent in Ne. furcosus. White, flattish larvae, about $1 \mathrm{~cm}$ in length, were found in the abdominal cavity and in almost all organs of this fish, including the intestinal lumen. Sometimes larvae were visible when the fish was caught, because they were protruding in the region around the anus, with half of their body buried in the flesh. We interpret these larvae as bothriocephalideans due to the lack of morphological characters.

Tetraphyllideans include small forms found in the intestinal lumen of various fishes, both from coralassociated and deeper water fishes. It is possible that these include lecanicephalideans. A detailed morphological examination was not performed.

\section{Cestoda Trypanorhyncha}

Only larvae were found. All these trypanorhynchs have their adults parasitic in sharks and are probably transmitted to their final host by predation. Seven species of larval trypanorhynch cestodes, all from coral-associated fish, were identified at the species level on the basis of the armature of their tentacles.

Trypanoselachoidans [98] included four species, found as larvae in cysts in the abdominal cavity. The otobothriid Otobothrium mugilis was found only once in the nemipterid Nemipterus furcosus. The lacistorhynchids Callitetrarhynchus gracilis, Floriceps minacanthus and Pseudolacistorhynchus heroniensis were found in a lutjanid and a nemipterid; in New Caledonia, C. gracilis has already been recorded from 4 serranids and 1 lethrinid, F. minacanthus from 6 serranids and 1 lethrinid, and Ps. heroniensis from 7 serranids and 2 lethrinids $[7,8]$ and show low host specificity at the larval stage. C. gracilis has already been found in Lu. vitta in Indonesia and $F$. minacanthus has already been found in Ne. furcosus in Indonesia [99]. Ne. furcosus is a new host record for $C$. gracilis, $L u$. vitta is a new host record for Ps. heroniensis and Ne. furcosus is a new geographical and new host record for O. mugilis.

Trypanobatoidans [98] included three species of the tentaculariid genus Nybelinia, found free in the intestinal lumen of the nemipterid Ne. furcosus. Ny. goreensis has already been found in Ne. furcosus in Indonesia [99] and in New Caledonia in 2 lethrinids [8]. Ne. furcosus is a new geographical and new host record for $N y$. indica and for Ny. queenslandensis.
It is likely that this high rate of records in Ne. furcosus is simply a consequence of its higher sampling (see also nematodes). In addition, cysts were repeatedly found in small numbers in the abdominal cavity of several deep water lutjanids. Although there is no direct evidence that these represent trypanorhynchs because they never contained larvae, the cysts (Figure 4), about $1 \mathrm{~cm}$ in length, were similar to sterile trypanorhynch cysts. We hypothesize that these larvae have a very long development time, perhaps related to the relatively cold deep water environment, and that the fish collected by us were too young to harbour fully developed larvae; deep water lutjanids have long life spans (30-40 years) [100].

\section{Nematoda}

The minimized number of taxa is 17 , including 9 species identified at the species level.

Nematodes recorded belonged to eight families, the Anisakidae, Camallanidae, Capillariidae, Cucullanidae, Gnathostomatidae, Philometridae, Physalopteridae and Trichosomoididae.

The Anisakidae is represented by both larvae and adults. Larvae were encapsulated on the surface of organs or free in the lumen of the intestine; a few were occasionally identified at the genus level (Anisakis sp., Hysterothylacium sp., Terranova sp.), but most were identified only at the family level. Most fish species, whether coral-associated $[7,8]$ or deep-sea, harbour these larvae, sometimes in very high numbers.

Adult anisakids included two newly described species of Raphidascaris (Ichthyascaris), one from the coral-

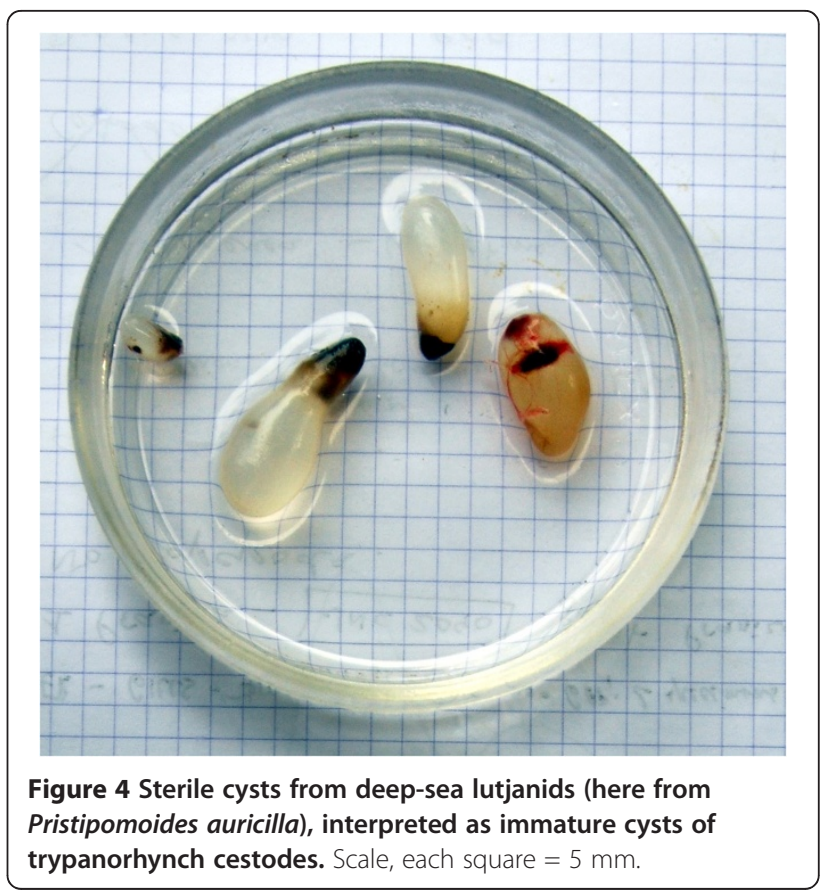


associated nemipterid Ne. furcosus, and one from the deep water lutjanid E. coruscans, and several additional specimens were found in other fish species and could not be identified at the species level.

Camallanids included one identified species, Camallanus carangis, and unidentified immature specimens.

Cucullanids were found only in deep water lutjanids, with Cucullanus bourdini in two species of Pristipomoides, and Dichelyne etelidis in two species of Etelis.

Unidentified gnathostomatids and physalopterids were occasionally found only in Ne. furcosus and probably illustrate the fact that this fish species was more intensively sampled that others, thus providing a number of records of parasites with low prevalence (see also trypanorhynchs).

Gonad-parasitic philometrids were found as two new species from $L u$. vitta, but never in other fish species. Lutjanids and nemipterids are known as hosts of a few species of gonad-parasitic philometrids in other regions, such as the North Pacific, Indian and Atlantic Oceans [101,102].

Capillariids included a newly described species, Pseudocapillaria novaecaledoniensis, from a deep water lutjanid, but no other records were made.

Trichosomoidids included two species of Huffmanela, H. branchialis and Huffmanela sp., from the gills of two nemipterids. Interestingly, both species recorded in 2004, were never found again, despite intensive sampling of Ne. furcosus; their prevalence is probably very low, and their initial discovery in a small sample should be attributed to chance. Similarly, no Huffmanela species was recorded from more than 500 serranids examined [7], but a new species was described later from a serranid [103]. Tissue-dwelling trichosomoidids are characterised by two opposing features which probably balance each other out - very low prevalences and extremely high numbers (millions) of eggs in the few individual fish infected.

\section{Hirudinea, 'Turbellaria' and Acanthocephala}

Specimens of these three groups were rarely found.

Juvenile specimens of the piscicolid leech Trachelobdella sp. were found on the gills of a lutjanid and a nemipterid. Leeches of this genus are known from other lutjanids [104,105].

Cysts containing an unknown turbellarian were found rarely on the gills of Ne. furcosus; these were orange, abundant but with a very low prevalence, and were not studied in detail. Parasitic turbellarians are rarely found on coral reef fish [106,107].

An unidentified acanthocephalan was found once in the intestine of the deep water Et. carbunculus; this record constitutes a small addition to our very poor knowledge of the acanthocephalans of New Caledonia fish $[6-8,108]$.

\section{A numerical evaluation of parasite biodiversity in lutjanids and nemipterids}

In presenting our results, we used the same methods as in previous similar papers of this series on serranids and lethrinids $[7,8]$.

Our results (Appendices 1 and 2) include a number of parasite identifications, but the level of taxonomic identification varies greatly. Table 1 details the number of HPCs found in each fish species, and indicates how many fish specimens were examined; it was compiled by counting each parasitological record (i.e. each line in Appendix 1) as a host-parasite combination (HPC).

The number of HPCs differs from the actual number of different parasite species, for two reasons (a) a parasite species present in several hosts is counted as several HPCs; and (b) HPCs in Table 1 enumerate records which vary widely in systematic precision, and may designate, in a decreasing order of taxonomic precision:

- Species-level identified parasites (SLIPs); these have full binomial names, and we do not include 'cf' identifications within them.

- Species-level identified parasites which have not yet received a binomial (such as the numbered copepods Hatschekia sp. 17-23, Diplectanum 'cf.' species, and numbered capsalids). These represent valid, independent species but a comparison of the presence of these species in other localities or in other fish species will not be possible until the parasite species are formally identified, described and names are published.

- Parasite species identified at the generic level only, but which probably represent only a single species (examples: several digeneans).

- Parasite species identified at the generic level only, but for which we already know that they represent several species (example: several ancyrocephalid monogeneans).

- Parasite species identified at the family or higher level, for which we know that abundant biodiversity is hidden within this HPC. This includes unidentifiable larvae such as gnathiid isopods, anisakid nematodes, didymozoid digeneans and tetraphyllidean metacestodes. We estimate that these may represent a total of about $50-100$ species.

Only species-level identified parasites with binomial (SLIPs) allow valid comparisons between localities and fish.

Table 1 includes all results, but some fishes were only studied superficially and their inclusion in further calculations would severely bias the results; for this reason, 
Table 3 was constructed only from fish species of which at least several specimens have been studied. Table 3 also provides a comparison with the lethrinids and serranids of New Caledonia, based on previous results $[7,8]$; this comparison will be discussed below. Of course, we are aware that the number of fish studied is generally too low to provide truly significant results on parasite biodiversity, but at least these results allow comparison with other fish families studied using the same methods in the same area. Caesionids are not included in Table 3 because only a single species was involved.

For lutjanids (Table 3), the total number of HPCs was 131, and the number of different parasite species identified at the species level (SLIPs) was 40. For nemipterids (Table 3), the total number of HPCs was 42 , and the number of SLIPs was 15. As usual, in addition, indistinguishable larval taxa probably correspond to a high number (50-100?) of different species, but cannot be differentiated on the basis of morphological studies.

Table 3 includes evaluations of these numbers as means per species of fish. The main results for all lutjanids (reef-associated and deeper sea) were that 10.92 HPCs were found per fish species, with 3.33 SLIPs (identified with binomial) per fish species. For nemipterids, the results were $14.00 \mathrm{HPCs}$ and 5.00 SLIPs per fish species.

\section{A comparison between reef-associated and deeper-water lutjanids}

Our results provide an opportunity to compare parasite biodiversity in reef-associated and deep water fishes. It is widely accepted that fishes in deeper waters have a lower

Table 3 Parasite biodiversity in lutjanids and nemipterids in New Caledonia for each parasite group, and a comparison with lethrinids and serranids

\begin{tabular}{|c|c|c|c|c|c|c|c|c|c|c|c|c|}
\hline Family or group & & Isop & Cope & Mono & Poly & Dige & Both & Tetr & Tryp & Nema & Other & Total \\
\hline Lutjanidae, reef-associated & HPCs & 2 & 6 & 30 & 2 & 24 & 2 & 4 & 2 & 9 & 0 & 81 \\
\hline $\begin{array}{l}\text { (species: } 8 * \text {; specimens: } \\
\text { 105; gill: 48; abdomen: } 72 \text { ) }\end{array}$ & SLIPs & 0 & 2 & 8 & 0 & 11 & 0 & 0 & 2 & 2 & 0 & 25 \\
\hline \multirow[t]{2}{*}{ Expressed as mean per fish species: } & HPCs mean & 0.25 & 0.75 & 3.75 & 0.25 & 3.00 & 0.25 & 0.50 & 0.25 & 1.13 & 0.00 & 10.13 \\
\hline & SLIPs mean & 0.00 & 0.25 & 1.00 & 0.00 & 1.25 & 0.00 & 0.00 & 0.25 & 0.25 & 0.00 & 3.13 \\
\hline Lutjanidae, deep-sea & HPCs & 5 & 10 & 7 & 1 & 12 & 0 & 2 & 3 & 9 & 1 & 50 \\
\hline $\begin{array}{l}\text { (species: } 4^{*} \text {; specimens: } \\
\text { 61; gill: 32; abdomen: } 28 \text { ) }\end{array}$ & SLIPs & 3 & 2 & 2 & 0 & 4 & 0 & 0 & 0 & 4 & 0 & 15 \\
\hline \multirow[t]{2}{*}{ Expressed as mean per fish species: } & HPCs mean & 1.25 & 2.50 & 1.75 & 0.25 & 3.00 & 0.00 & 0.50 & 0.75 & 2.25 & 0.25 & 12.50 \\
\hline & SLIPs mean & 0.75 & 0.50 & 0.50 & 0.00 & 1.00 & 0.00 & 0.00 & 0.00 & 1.00 & 0.00 & 3.75 \\
\hline Lutjanidae, all & HPCs & 7 & 16 & 37 & 3 & 36 & 2 & 6 & 5 & 18 & 1 & 131 \\
\hline $\begin{array}{l}\text { (species: 12*; specimens: } \\
\text { 166; gill: 80; abdomen: 100) }\end{array}$ & SLIPs & 3 & 4 & 10 & 0 & 15 & 0 & 0 & 2 & 6 & 0 & 40 \\
\hline \multirow[t]{2}{*}{ Expressed as mean per fish species: } & HPCs mean & 0.58 & 1.33 & 3.08 & 0.25 & 3.00 & 0.17 & 0.50 & 0.42 & 1.50 & 0.08 & 10.92 \\
\hline & SLIPs mean & 0.33 & 0.33 & 0.83 & 0.00 & 1.25 & 0.00 & 0.00 & 0.17 & 0.50 & 0.00 & 3.33 \\
\hline Nemipteridae & HPCs & 3 & 1 & 4 & 2 & 11 & 1 & 2 & 6 & 10 & 2 & 42 \\
\hline $\begin{array}{l}\text { (species: } 3^{*} \text {; specimens: } \\
\text { 274; gill: 138; abdomen: } 181 \text { ) }\end{array}$ & SLIPs & 0 & 0 & 1 & 0 & 5 & 0 & 0 & 6 & 3 & 0 & 15 \\
\hline \multirow[t]{2}{*}{ Expressed as mean per fish species: } & HPCs mean & 1.00 & 0.33 & 1.33 & 0.67 & 3.67 & 0.33 & 0.67 & 2.00 & 3.33 & 0.67 & 14.00 \\
\hline & SLIPs mean & 0.00 & 0.00 & 0.33 & 0.00 & 1.67 & 0.00 & 0.00 & 2.00 & 1.00 & 0.00 & 5.00 \\
\hline Lethrinidae & HPCs & 9 & 21 & 53 & 4 & 59 & 1 & 7 & 10 & 21 & 3 & 188 \\
\hline $\begin{array}{l}\text { (17 species: 17; specimens: } \\
\text { 423; gill: 227; abdomen: } 334 \text { ) } \\
\end{array}$ & SLIPs & 0 & 7 & 11 & 0 & 13 & 0 & 0 & 6 & 5 & 0 & 42 \\
\hline \multirow[t]{2}{*}{ Expressed as mean per fish species: } & HPCs mean & 0.53 & 1.24 & 3.12 & 0.24 & 3.47 & 0.06 & 0.41 & 0.59 & 1.24 & 0.18 & 11.06 \\
\hline & SLIPs mean & 0.00 & 0.41 & 0.65 & 0.00 & 0.76 & 0.00 & 0.00 & 0.35 & 0.29 & 0.00 & 2.47 \\
\hline Serranidae & HPCs & 20 & 53 & 97 & 0 & 76 & 4 & 13 & 35 & 37 & 2 & 337 \\
\hline $\begin{array}{l}28 \text { species, specimens: 540; } \\
\text { gill: 394; abdomen: } 275 \text { ) }\end{array}$ & SLIPs & 3 & 7 & 42 & 0 & 13 & 1 & 0 & 5 & 4 & 0 & 75 \\
\hline \multirow[t]{2}{*}{ Expressed as mean per fish species: } & HPCs mean & 0.71 & 1.89 & 3.46 & 0.00 & 2.71 & 0.14 & 0.46 & 1.25 & 1.32 & 0.07 & 12.04 \\
\hline & SLIPs mean & 0.11 & 0.25 & 1.50 & 0.00 & 0.46 & 0.04 & 0.00 & 0.18 & 0.14 & 0.00 & 2.68 \\
\hline
\end{tabular}

HPCs, number of host-parasite combinations; SLIPs: number of species-level identified parasites (the same parasite species found in different hosts is counted a single time; hence differences with numbers of SLIP-HPCs in Table 1). Source of data for lutjanids and nemipterids: Table 1 and Appendix 2, this paper; for lethrinids and serranids, Table 3 in [8].

*: species with only anecdotal data (see Table 1) were excluded from these calculations. 
parasitic diversity than surface fishes [109-112]. However, in comparative studies, fish species from the deep-sea are generally from orders (e.g. Gadiformes, Ophidiiformes, Notacanthiformes) which are different from the orders of surface fishes (e.g. Perciformes); in contrast, our study allows us to compare fish from the same family, the Lutjanidae, from both environments. Moreover, collection areas were very close and adjacent, with deeper-water fishes collected from just off the barrier reef along the outer slope, i.e. less than one kilometre away from the barrier reef and the lagoon [19]. Recently, a molecular study demonstrated that monogeneans of groupers tend to widen specificity when they infect fish from the outer slope, in comparison to lagoon fish where they are strictly specific [23].

Table 3 shows that the number of HPCs in reefassociated lutjanids was 10.13 per fish species, compared with 12.50 (123\%) in deep-water lutjanids. The number of SLIPs in reef-associated lutjanids was 3.13 per fish species, compared with 3.75 (125\%) in deeper water lutjanids. These figures suggest that parasite biodiversity was higher in deeper-water fishes than in reef-associated fishes, a highly unexpected result.

However, we identify four biases which diminish the validity of this comparison:

(a) Depth bias. Estimates of parasite biodiversity in deep-sea fish [109-112] generally concern fish from deeper seas (i.e. $1000 \mathrm{~m}$ vs 100-250 m) and from other fish orders than those studied here. (b) Size bias. Most deeper water fish examined, especially Etelis spp., were large fish, usually in the metre range size, while reef lutjanids were smaller, usually $10-30 \mathrm{~cm}$ in length [113]. It is known that parasite biodiversity increases with the size of hosts $[8,114,115]$.

(c) Monogenean bias. Coral-associated lutjanids harbour a number of small ancyrocephalid monogeneans, of which a large proportion has not been described yet [45].

(d) Human bias. The high number of parasites identified at the species level in deeper water fish is probably related to the scientific interest they elicit in scientists. Systematicians like to describe rare parasites from rarely examined fish! No particular direction was given to participants of this study to balance their descriptive effort between reef and deeper water fish.

\section{A comparison with lethrinids and serranids}

Data on parasite biodiversity, compiled using the same methods at the same location, are available for two other families $[7,8]$.

Table 4 compares parasite biodiversity in four families of reef-associated fishes, the lutjanids and nemipterids (present study), and the serranids and lethrinids $[7,8]$. Table 4 also compares results for data compiled from fishes with variable sample size (anecdotal collections excluded) and for fishes with significant sampling (i.e. $>25$ individuals). For the latter, the numbers of HPCs for lutjanids and nemipterids per fish species are 20.00 and

Table 4 Parasite biodiversity in reef-associated families: lutjanids and nemipterids compared with lethrinids and serranids, and a calculation on all four families

\begin{tabular}{|c|c|c|c|c|c|c|}
\hline Family or group & & All data & Well-sampled & & All data & Well- sampled \\
\hline Lutjanidae, reef-associated & HPCs & 81 & 20 & HPCs mean & 10.13 & 20.00 \\
\hline $\begin{array}{l}\text { (All data: } 8 \text { species*; } \\
\text { well-sampled: } 1 \text { species**) }\end{array}$ & SLIPs & 25 & 9 & SLIPs mean & 3.13 & 9.00 \\
\hline Nemipteridae & HPCs & 42 & 25 & HPCs mean & 14.00 & 25.00 \\
\hline $\begin{array}{l}\text { (All data: } 3 \text { species*; } \\
\text { well-sampled: } 1 \text { species**) }\end{array}$ & SLIPs & 15 & 13 & SLIPs mean & 5.00 & 13.00 \\
\hline Lethrinidae & HPCs & 188 & 89 & HPCs mean & 11.06 & 22.25 \\
\hline $\begin{array}{l}\text { (All data: } 17 \text { species; } \\
\text { well-sampled: } 4 \text { species) }\end{array}$ & SLIPs & 42 & 38 & SLIPs mean & 2.47 & 9.50 \\
\hline Serranidae & HPCs & 337 & 136 & HPCs mean & 12.04 & 19.43 \\
\hline $\begin{array}{l}\text { (All data: } 28 \text { species; } \\
\text { well-sampled: } 7 \text { species) }\end{array}$ & SLIPs & 75 & 74 & SLIPs mean & 2.68 & 10.57 \\
\hline Four families of reef-associated fish & HPCs & 648 & 270 & HPCs mean & 11.57 & 20.77 \\
\hline $\begin{array}{l}\text { (All data: } 56 \text { species; } \\
\text { well-sampled: } 13 \text { species)*** }\end{array}$ & SLIPs & 148 & 125 & SLIPs mean & 2.64 & 9.62 \\
\hline
\end{tabular}

*: species with only anecdotal data (see Table 1) were excluded from these calculations.

** species sampled over 30: Lutjanidae, only Lutjanus vitta $(n=42)$; Nemipteridae, only Nemipterus furcosus $(n=239)$.

*** SLIPs for all four families are not a simple addition of SLIPs for each families, because a few taxa are shared. These include only the digenean Stephanostomum japonocasum (shared by 2 fish families), and the four trypanorhynchs C. gracilis (shared by 4 families), F. minacanthus, Ps. heroniensis and Ny. goreensis (shared by $2-3$ families). 
25.00, respectively, and the number of SLIPs are 9.00 and 13.00, respectively. These results are similar to previous results in serranids and lethrinids, in which HPCs in well-sampled fishes were 19.43 and 22.25 , respectively, and SLIPs were 10.57 and 9.50, respectively. Results for all fishes (including species with low sample size, but excluding anecdotal collections) constitute about half of these figures.

In addition, Table 4 includes results obtained by pooling the data for all four families of fish. Results from 13 species of well-sampled reef-associated fishes (only $\mathrm{n}>25$ or $\mathrm{n}>30$ sampled individuals according to family), represented a sampling effort of almost 1,000 fishes (382 serranids, 329 lethrinids, 42 lutjanids, 239 nemipterids, total 992). The sampling effort and person-day time represented by these figures, which include collection, preparation, precise identification of parasite specimens, and curation in recognized collections, has no equivalent in the literature for reef-associated fish and all of their parasites (although similar efforts were devoted to digeneans only $[4,116,117])$. The number of HPCs is 20.77 per fish species, and the number of SLIPs is 9.62 per fish species. Many precautions were taken in these studies to minimize the number of taxa, and larval taxa (which are difficult to identify) certainly represent a significant additional biodiversity. We thus consider that the total result of ten species of parasites per reef fish species is a strict minimum, and that the real number is probably double or triple this estimate. All numbers here concern only macroparasites; the addition of Myxosporea, if they were known, would significantly enhance all results, with probably 2-3 additional parasite species per fish species $[118,119]$.

Our published [6,81,120-124] and unpublished data on other families of fish suggest that this number of 10 species of parasites per fish species is generalizable to other families of fish, at least those with similar "average" size $(10-40 \mathrm{~cm})$, since parasite biodiversity depends upon the size of fish $[4,8]$.

As found for serranids and lethrinids $[7,8]$, the literature includes very few extensive lists of parasites from lutjanids and nemipterids in the Pacific. The checklist of parasites of Heron Island [44] includes a single lutjanid species in common with the present study, $L u$. fulviflamma, with a single parasite record, and no nemipterid species in common. This precludes any biogeographical comparison for lutjanids and nemipterids, as was found for serranids and lethrinids $[7,8]$.

\section{Consequences for coextinction of parasites of coral reef fish}

The word coextinction was coined by Stork and Lyal (1993) [125] to express that as a host species becomes extinct, so does one or more species of parasites, and was redefined by Koh et al. (2004) [126] in a slightly broader sense as "the loss of a species (the affiliate) upon the loss of another (the host)".

Knowing that parasite species are more numerous than non-parasitic species $[127,128]$, it follows that coextinctions are more numerous than extinctions [129]. Dobson et al. (2008) [130] estimated that 3-5\% of helminths are threatened by extinction in the next 50 100 years. However, Dunn (2009) [129] mentioned that there is no well documented case of the coextinction of a vertebrate parasite. Rózsa (1992) [131] pointed out that even a decrease in numbers within a host population, without the danger of extinction, could jeopardize the survival of certain parasite species. Koh et al. (2004) [126] calculated a risk of extinction of 593 species of monogeneans associated with 746 endangered species of fish. Justine (2007) [132] remarked that such a prediction underestimated the number of parasites in fish in rich ecosystems such as coral reefs. For Moir et al (2010) [133], this discrepancy highlights how biogeographic variation and knowledge gaps in dependant species biodiversity may lead to biased estimates of coextinction risk.

Should we be concerned by the extinction of parasites? This is hard to defend to the general public, because "parasites tend to lack charisma" [129] and many bloodsucking parasites transmit diseases [134]. However, parasites play a major role in the balance of populations and the evolution of their hosts $[114,129,130,135]$, and, as such, are an important and irreplaceable part of biodiversity and ecosystems.

The numerical evaluation of parasitic biodiversity in coral reef fish provided in the present study allows a more precise prediction of the risk of coextinction if a coral reef fish species becomes extinct, or simply has its population decreased [133]. Coral reefs are threatened across the planet [136-140] and special threats exist in New Caledonia [141,142]. Our results suggest that extinction of a coral reef fish species of average size would eventually result in the co-extinction of at least ten species of parasites.

\section{Conclusions}

As surprising as it might seem for studies mainly based on lists of parasites and morphological identifications, the present paper and our two previous similar papers $[7,8]$ are pioneering works in the field of biodiversity of parasites of tropical coral reef fishes. Our main discovery of a parasitic biodiversity at least ten times higher than fish biodiversity has potential implications in the evaluation of loss of biodiversity when a coral reef fish species is threatened or becomes extinct. 


\section{Methods}

Methods used in this paper are essentially the same as for the two previous papers of this series $[7,8]$ and for brevity are not repeated here. For parasite collection, we used two methods targeting two sets of organs, designated as "gills" and "abdominal organs". We generally used the "gut wash" method [143] but in some circumstances we used a simplified method [144]. Full details and possible methodological flaws were discussed previously $[7,8]$. In addition, we soaked a few fish in saline in order to collect surface monogeneans. A high number (239) of fork-tailed threadfin breams, Nemipterus furcosus, were examined, including specimens examined for research and specimens examined by students during practical courses at the University of New Caledonia.

Parasite specimens, generally collected by J.-L. Justine and his team, and sometimes by visiting colleagues, were forwarded to respective specialists: I. Beveridge (trypanorhynch cestodes), G. A. Boxshall (copepods), R. A. Bray and T. L. Miller (digeneans), F. Moravec (nematodes), J.-P. Trilles (isopods), I. D. Whittington (capsalid monogeneans), and J.-L. Justine (other monogeneans). Hirudineans were examined by E. Burreson (College of William and Mary, Gloucester Point, Virginia, USA); a few monogeneans were examined by L. Euzet (Sète, France); some anisakids were identified at the generic level by S. Shamsi (Charles Sturt University, Wagga Wagga, NSW, Australia). Gills of several lutjanids, prepared with hot water and formalin, were examined by D. C. Kritsky (Idaho State University, Pocatello, Idaho, USA) and monogeneans were described [45]. Sometimes external isopods were brought by fishermen and provided "anecdotal" collections.

The names of cestode orders and suborders follow Khalil et al. [145] updated by recent work [98,146,147]. Polyopisthocotylean and monopisthocotylean monogeneans are treated as two independent groups, because monophyly of the monogeneans is not established [148-152]. However, since polyopisthocotyleans were rare, results for both groups were often pooled. Monogeneans sometimes included in the Dactylogyridae are here considered as members of the Ancyrocephalidae $[153,154]$. Many specimens have been deposited in recognized collections (Appendix 3); other specimens under study are still in the collections of the various authors but will be eventually deposited in the collection of the Muséum National d'Histoire Naturelle, Paris, France $(\mathrm{MNHN})$ and/or in other recognized, curated collections.

Research carried out on animals (fish) was performed in accordance with the ethical requirements of the IRD (Institut de Recherche pour le Développement, France) and University of Adelaide Animal Ethics Approval S020-2008 for work by I.D. Whittington.

\section{Appendix 1. Host-parasite list}

New, unpublished records indicated by [0]; other records: $[6,24,25,45,47,58,59,71,78,79,81,87,88,107,155-166]$.

8 fish species with low sample size * were included in Table 1 but not kept in final calculations of parasite numbers (Table 3 ).

\section{Caesionidae \\ Caesio cuning (Bloch, 1791)}

Dige: Hemi: Lecithochirium sp. (digestive tract) [0]

Dige: Leci: Aponurus sp. (digestive tract) [0]

Both: Unid: unidentified larvae (digestive tract) [0]

Tetr: Unid: unidentified larvae (digestive tract) [0]

Nema: Cucu: Cucullanus sp. (digestive tract) [0]

Remarks: 8 specimens examined (4 for gills, 8 for abdominal organs)

HPCs: 5; SLIP-HPCs: 0.

\section{Lutjanidae, reef-associated \\ Aprion virescens Valenciennes, 1830}

Mono: Caps: Pseudonitzschia uku (gills) [58]

Dige: Acan: Pleorchis uku, immature (intestine) [81]

Dige: Acan: Stephanostomum uku (intestine) [81]

Remarks: 3 specimens examined (3 for gills, 3 for abdominal organs)

HPCs: 3; SLIP-HPCs: 3.

Lutjanus adetii (Castelnau, 1873)

Dige: Opec: Hamacreadium mutabile (digestive tract)

[0]

Dige: Scle: Prosogonotrema bilabiatum immature

(digestive tract) [0] (NGR)

Both: Unid: unidentified larvae (digestive tract) [0]

Nema: Anis: unidentified larvae (abdominal cavity) [0]

Remarks: 5 specimens examined (0 for gills, 5 for abdominal organs)

HPCs: 4; SLIP-HPCs: 2.

\section{Lutjanus argentimaculatus (Forsskål, 1775)}

Isop: Gnat: Praniza larvae (gills) [0]

Cope: Hats: Hatschekia n. sp. 20 (gills) [0]

Cope: Lerp: Parabrachiella lutiani (gills) [0] (NHR)

Mono: Ancy: Euryhaliotrema sp. (gills) [45]

Mono: Ancy: Haliotrematoides novaecaledoniae

(gills) [45]

Mono: Ancy: Haliotrematoides potens (gills) [45]

Mono: Caps: Metabenedeniella sp. (pectoral fins) [59] 
Mono: Caps: Trilobiodiscus lutiani (gills) [59] (NGR) Dige: Cryp: Retrovarium manteri (digestive tract) [0] (NGR)

Dige: Cryp: Retrovarium saccatum (digestive tract) [0] (NHR)

Dige: Cryp: Siphoderina hirastricta (digestive tract) [0] (NGR)

Dige: Opec: Hamacreadium mutabile (digestive tract)

[0] (NHR)

Tetr: Unid: unidentified larvae (digestive tract) [0]

Remarks: 4 specimens examined (3 for gills, 3 for abdominal organs)

HPCs: 13; SLIP-HPCs: 8.

\section{Lutjanus fulviflamma (Forsskål, 1775)}

Cope: Cali: Chalimus larvae (gills) [0]

Cope: Hats: Hatschekia tanysoma (gills) [0] (NGR)

Mono: Ancy: Euryhaliotrema sp.(gills) [45]

Mono: Ancy: Haliotrematoides patellacirrus (gills) [45]

Mono: Ancy: Haliotrematoides tainophallus (gills) [45]

Poly: Unid (gills) [0]

Dige: Cryp: Euryakaina marina (intestine) [78]

Dige: Opec: Hamacreadium mutabile (digestive tract) [0]

Nema: Anis: unidentified larvae (abdominal cavity) [0]

Remarks: 17 specimens examined (11 for gills, 11 for abdominal organs)

HPCs: 9; SLIP-HPCs: 5.

\section{Lutjanus fulvus (Forster, 1801) *}

Mono: Ancy: Euryhaliotrema sp. (gills) [45]

Mono: Ancy: Haliotrematoides longitubocirrus (gills)

[45]

Mono: Ancy: Haliotrematoides patellacirrus (gills) [45]

Mono: Ancy: unidentified (gills) [45]

Remarks: 2 specimens examined (1 for gills, 0 for abdominal organs, additional gills examined by D. C. Kritsky). * Fish species not kept for final parasite counts (Table 3) because of low sample size.

HPCs: 4; SLIP-HPCs: 2.

\section{Lutjanus gibbus (Forsskål, 1775) *}

Cope: Hats Hatschekia clava (gills) [0] (NHR)

Mono: Ancy: unidentified (gills) [0]

Remarks: 2 specimens examined ( 2 for gills, 1 for abdominal organs). * Fish species not kept for final parasite counts (Table 3 ) because of low sample size.

HPCs: 2; SLIP-HPCs: 1.

\section{Lutjanus kasmira (Forsskål, 1775)}

Cope: Hats: Hatschekia n. sp. 19 (gills) [0]

Mono: Dipl: Diplectanum cf. fusiforme (gills) [0]

Mono: Dipl: Diplectanum cf. spirale (gills) [0]

Mono: Ancy: unidentified sp. 1 (gills) [0] [45]

Mono: Ancy: unidentified sp. 2 (gills) [0]

Mono: Ancy: unidentified sp. 3 (gills) [0]

Mono: Ancy: unidentified sp. 4 (gills) [0]

Dige: Cryp: Siphoderina sp. (digestive tract) [0]

Dige: Didy: unidentified larvae (digestive tract) [0]

Dige: Hemi: Lecithochirium sp. (digestive tract) [0]

Dige: Opec: Hamacreadium mutabile (digestive tract)

[163]

Dige: Tran: Transversotrema borboleta (under scales)

[0] (NGR)

Both: Unid: unidentified larvae (digestive tract) [0]

Tetr: Unid: unidentified larvae (digestive tract) [0]

Nema: Anis: unidentified larvae (abdominal cavity) [0]

Remarks: 16 specimens examined (12 for gills, 12 for abdominal organs, 2 soaked bodies for skin parasites, additional gills examined by D. C. Kritsky)

HPCs: 15; SLIP-HPCs: 1.

\section{Lutjanus monostigma (Cuvier, 1828) *}

Isop: Cora: Argathona macronema (body) [0] (NHR)

Remarks: 0 specimen examined (external isopod collected from one fish otherwise not examined). * Fish species not kept for final parasite counts (Table 3) because of low sample size.

HPCs: 1; SLIP-HPCs: 1.

\section{Lutjanus quinquelineatus (Bloch, 1790)}

Mono: Ancy: Euryhaliotrema sp. (gills) [45]

Mono: Ancy: Haliotrematoides lanx (gills) [45]

Mono: Ancy: Haliotrematoides longitubocirrus (gills)

[45]

Mono: Ancy: Haliotrematoides patellacirrus (gills)

[45]

Mono: Ancy: unidentified (gills) [45]

Dige: Cryp: Varialvus charadrus (intestine) [79]

Dige: Opec: Hamacreadium mutabile (intestine) [0]

Tetr: Unid: unidentified larvae (digestive tract) [0]

Nema: Anis: unidentified larvae (abdominal cavity) [0]

Remarks: 12 specimens examined ( 0 for gills, 6 for abdominal organs, additional gills examined by D. C. Kritsky)

HPCs: 9; SLIP-HPCs: 5. 


\section{Lutjanus rivulatus (Cuvier, 1828) *}

Mono: Ancy: unidentified sp. (gills) [0]

Nema: Anis: unidentified larvae (abdominal cavity) [0]

Hiru: Pisc: Trachelobdella sp. immature (gills) [0]

Remarks: 2 specimens examined ( 2 for gills, 2 for abdominal organs; including 1 juvenile). "Fish species not kept for final parasite counts (Table 3) because of low sample size.

HPCs: 3; SLIP-HPCs: 0.

\section{Lutjanus russellii (Bleeker, 1849)}

Isop: Gnat: Praniza larvae (gills) [0]

Mono: Ancy: Euryhaliotrema sp. (gills) [45]

Mono: Ancy: Haliotrematoides longitubocirrus (gills)

[45]

Mono: Ancy: Haliotrematoides patellacirrus (gills)

[45]

Mono: Caps: Capsalidae sp. 6 (body washing) [59]

Poly: Unid: unidentified immature (gills) [0]

Dige: Didy: unidentified larvae (intestine) [0]

Dige: Opec: Hamacreadium mutabile (intestine) [0]

Remarks: 6 specimens examined (0 for gills, 1 for abdominal organs, additional gills examined by D. C. Kritsky) HPCs: 8; SLIP-HPCs: 3.

\section{Lutjanus vitta (Quoy \& Gaimard, 1824)}

Cope: Cali: chalimus larvae (gills) [0]

Mono: Ancy: Euryhaliotrema sp. (gills) [45]

Mono: Ancy: Haliotrematoides longitubocirrus (gills)

[45]

Mono: Ancy: Haliotrematoides patellacirrus (gills)

[45]

Mono: Ancy: unidentified (gills) [45]

Mono: Caps: Capsalidae sp. 7 (branchiostegal

membranes) [59]

Mono: Dipl: Diplectanum cf. fusiforme (gills) [0]

Dige: Cryp: Euryakaina manilensis (intestine) [78]

Dige: Cryp: Varialvus charadrus (intestine) [79]

Dige: Didy: unidentified larvae (intestine) [0]

Dige: Hemi: Lecithochirium sp. (intestine) [0]

Dige: Opec: Hamacreadium mutabile (intestine) [0]

(NHR)

Tetr: Unid: unidentified (intestine) [0]

Tryp: Laci: Callitetrarhynchus gracilis (abdominal cavity) [0]

Tryp: Laci: Pseudolacistorhynchus heroniensis (abdominal cavity) [0] (NHR)

Nema: Anis: Raphidascaris (Ichthyascaris) sp. (intestine) [161]
Nema: Anis: Terranova sp. larvae (abdominal cavity)

[0]

Nema: Cama: unidentified larvae (intestine) [0]

Nema: Phil: Philometra brevicollis (gonads) [160]; as "sp" [165]

Nema: Phil: Philometra mira (gonads) [160]; as "sp" [165]

Remarks: 42 specimens examined (19 for gills, 31 for abdominal organs, 5 unproductive soaked bodies, additional gills examined by D. C. Kritsky)

HPCs: 20; SLIP-HPCs: 9.

\section{Macolor niger (Forsskål, 1775) *}

Cope: Cali: Caligus n. sp. 2 (gills) [0]

Cope: Diss: Dissonus excavatus (gills) [155]

Cope: Hats: Hatschekia n. sp. 18 (gills) [0]

Mono: Caps: unidentified (gills) [0]

Mono: Gyro: unidentified (gills) [0]

Dige: Hemi: Lecithochirium sp. (intestine) [0]

Remarks: 2 specimens examined ( 2 for gills, 1 for abdominal organs). "Fish species not kept for final parasite counts (Table 3 ) because of low sample size.

HPCs: 6; SLIP-HPCs: 1.

\section{Lutjanidae, deep water}

Etelis carbunculus Cuvier, 1828

Isop: Cymo: Anilocra gigantea (body) [0]

Cope: Cali: Caligus brevis (body) [0] (NHR)

Cope: Cali: chalimus larvae (gills) [0]

Cope: Hats: Hatschekia n. sp. 21 (gills) [0]

Cope: Lerp: Parabrachiella sp. 2 (body) [0]

Mono: Caps: Benedenia elongata (gills) [0] (NHR)

(NGR)

Dige: Cryp: Siphoderina ulaula (digestive tract) [0]

(NGR)

Dige: Didy: unidentified adults (under scales) [0]

Dige: Opec: Neolebouria blatta (digestive tract) [87]

Tetr: Unid: unidentified larvae (digestive tract) [0]

Tryp: Unid: unidentified larvae, sterile cysts (abdominal cavity) [0]

Nema: Anis: Raphidascaris (Ichthyascaris) sp. (digestive tract) [0]

Nema: Cucu: Dichelyne etelidis (digestive tract) [159]

Acan: Unid: unidentified (digestive tract) [0]

Remarks: 16 specimens examined (5 for gills, 3 for abdominal organs, occasional collect of skin isopods or didymozoids)

HPCs: 14; SLIP-HPCs: 6. 


\section{Etelis coruscans Valenciennes, 1862}

Isop: Cymo: Anilocra gigantea (body) [0] (NHR)

Cope: Cali: Caligus brevis (body) [0] (NHR)

Cope: Cali: chalimus larvae (body) [0]

Cope: Penn: chalimus larvae and premetamorphic

adults (body) [0]

Cope: Hats: Hatschekia n. sp. 21 (gills) [0]

Mono: Caps: Benedenia elongata (gills) [0] (NHR)

(NGR)

Mono: Caps: Lagenivaginopseudobenedenia etelis (gills)

[0] (NHR)(NGR)

Poly: Micr: Allomicrocotyla sp. (gills) Euzet det.

Dige: Cryp: Siphoderina cf. onaga (digestive tract) [0]

Dige: Cryp: Siphoderina n. sp. (digestive tract) [0]

Dige: Fell: Tergestia magna (digestive tract) [0] (NGR)

(NHR)

Tryp: Unid: unidentified larvae, sterile cysts (abdominal cavity) [0]

Nema: Anis: Raphidascaris (Ichthyascaris) etelidis

(digestive tract) [161]

Nema: Cucu: Dichelyne etelidis (digestive tract) [159]

Remarks: 18 specimens examined (11 for gills, 5 for abdominal organs, occasional collect of skin isopods or didymozoids); The taxon listed as Lagenivaginopseudobenedenia sp. and sequenced in [59] is actually likely to be Benedenia elongata (I.D. Whittington, unpublished)

HPCs: 14; SLIP-HPCs: 7.

\section{Pristipomoides argyrogrammicus (Valenciennes, 1832)}

Isop: Cymo: Anilocra longicauda (body) [0] (NHR)

(NGR)

Cope: Lerp: Clavellotis sp. (pectoral fins) [6,162]

Mono: Caps: Benedenia elongata (gills) [0] (NHR)

(NGR)

Mono: Caps: Capsalidae sp. 17 (head) [59]

Mono: Dipl: Diplectanum cf. curvivagina (gills) [0]

Dige: Cryp: Metadena rooseveltiae (digestive tract) [0]

(NHR)(NGR)

Dige: Cryp: Siphoderina n. sp. (digestive tract) [0]

Dige: Cryp: Siphoderina ulaula (digestive tract) [0]

(NHR)(NGR)

Dige: Opec: Neolebouria blatta (digestive tract) [87]

Tetr: Unid: unidentified (intestine) [0]

Tryp: Unid: unidentified larvae, sterile cysts (abdominal cavity) [0]

Nema: Anis: unidentified larvae (abdominal cavity) [0]

Nema: Capi: Pseudocapillaria novaecaledoniensis

(digestive tract) [158]

Remarks: 20 specimens examined (14 for gills, 18 for abdominal organs, 1 soaked body). The taxon listed as
Capsalidae sp. 17 and sequenced in [166] (no mounted voucher specimen available) is actually likely to be Benedenia elongata (I.D. Whittington, unpublished)

HPCs: 13; SLIP-HPCs: 6.

Pristipomoides auricilla (Jordan, Evermann \& Tanaka, 1927)

Isop: Gnat: Praniza larvae (gills) [0]

Mono: Dipl: Diplectanum cf. opakapaka (gills) [0]

Dige: Lepo: Lepidapedoides kalikali (stomach) [0]

(NGR)

Tetr: Unid: unidentified larvae (intestine) [0]

Tryp: Unid: unidentified larvae, sterile cysts (abdominal cavity) [0]

Nema: Anis: unidentified larvae (abdominal cavity) [0]

Nema: Cama: unidentified adults (digestive tract) [0]

Nema: Cucu: Cucullanus bourdini (digestive tract)

[159]

Remarks: 2 specimens examined ( 2 for gills, 2 for abdominal organs)

HPCs: 8; SLIP-HPCs: 2.

\section{Pristipomoides filamentosus (Valenciennes, 1830) *}

Isop: Aegi: Aega musorstom (body) [0] (NHR)

Isop: Cymo: Anilocra gigantea (body) [0] (NHR)

Cope: Penn: Lernaeolophus sultanus (body) [0] (NHR)

Mono: Dipl: Diplectanum sp. (gills) [0]

Dige: Didy: unidentified adults (digestive tract) [0]

Dige: Didy: unidentified larvae (digestive tract) [0]

Nema: Anis: Raphidascaris (Ichthyascaris) etelidis

(digestive tract) [161]

Nema: Cama: Camallanus sp. (digestive tract) [0]

Nema: Cucu: Cucullanus bourdini (digestive tract)

[159]

Remarks: 7 specimens examined ( 2 for gills, 2 for abdominal organs, occasional collect of external isopods or copepods). "Fish species not kept for final parasite counts (Table 3 ) because of low sample size.

HPCs: 9; SLIP-HPCs: 5.

\section{Nemipteridae}

Nemipterus furcosus (Valenciennes, 1830)

Isop: Gnat: Praniza larvae (gills) [0]

Mono: Caps: unidentified (gills) (“Benedenia sp." [156])

Mono: Caps: Capsalidae sp. 13 (pelvic and anal fins,

gills, branchiostegal membranes) [0] (branchiostegal

membranes) [59]

Poly: Micr: unidentified immature (gills) [156]

Dige: Cryp: Adlardia novaecaledoniae (intestine)

$[71,164]$ 
Dige: Didy: unidentified larvae (digestive tract) [0]

Dige: Hemi: Ectenurus trachuri (digestive tract) [0] (NGR)(NHR)

Dige: Opec: Macvicaria jagannathi (digestive tract)

[87]

Dige: Opec: Neolebouria lineatus (digestive tract) [87]

Both: Unid: unidentified larvae (abdominal cavity and intestine) [0]

Tetr: Unid: unidentified larvae (intestine) [0]

Tryp: Laci: Callitetrarhynchus gracilis larvae

(abdominal cavity) [0] (NHR)

Tryp: Laci: Floriceps minacanthus larvae (abdominal cavity) [0]

Tryp: Otob: Otobothrium mugilis larvae (intestine) [0]

Tryp: Tent: Nybelinia goreensis larvae (intestine) [0]

Tryp: Tent: Nybelinia indica larvae (intestine) [0]

(NHR)(NGR)

Tryp: Tent: Nybelinia queenslandensis larvae (intestine)

[0] (NHR)(NGR)

Nema: Anis: Anisakis sp. larvae (abdominal cavity) [0]

Nema: Anis: Hysterothylacium sp. larvae (abdominal cavity) [0]

Nema: Anis: Raphidascaris (Ichthyascaris) nemipteri adults (intestine) [157]

Nema: Cama: Camallanus carangis adults (intestine)

[166]

Nema: Gnto: unidentified larvae (intestine) [0]

Nema: Phys: unidentified larvae (intestine) [0]

Nema: Tric: Huffmanela branchialis eggs (gills) [24]

Turb: Unid: unidentified adults (gills) [107]

Remarks: 239 specimens examined (111 for gills, 160 for abdominal organs, branchiostegal membranes examined)

HPCs: 25; SLIP-HPCs: 13.

\section{Pentapodus aureofasciatus Russell, 2001}

Isop: Gnat: Praniza larvae (gills) [156]

Cope: Hats: Hatschekia n. sp. 17 (gills) [0]; as "sp.” [47]

Mono: Ancy: unidentified (gills) [0]

Mono: Dipl: Calydiscoides limae (gills) [156]

Poly: Micr: unidentified immature (gills) [156]

Dige: Hemi: Lecithochirium sp. (digestive tract) [0]

Dige: Hemi: Lecithocladium sp. (digestive tract) [0]

Dige: Opec: Neochoanostoma sp. (digestive tract) [0]

Dige: Opec: Neolebouria sp. (digestive tract) [0]

Tetr: Unid: unidentified larvae (intestine) [0]

Nema: Anis: unidentified larvae (abdominal cavity) [0]

Nema: Tric: Huffmanela sp. eggs (gills) [24] [25]

Remarks: 23 specimens examined (19 for gills, 12 for abdominal organs)

HPCs: 12; SLIP-HPCs: 1.
Pentapodus nagasakiensis (Tanaka, 1915) *

Dige: Hemi: Lecithochirium sp. (digestive tract) [0]

Dige: Opec: Macvicaria sp. (digestive tract) [0]

Tetr: Unid: unidentified larvae (intestine) [0]

Nema: Anis: unidentified larvae (abdominal cavity) [0]

Remarks: 2 specimens examined (2 for gills, 2 for abdominal organs). * Fish species not kept for final parasite counts (Table 3 ) because of low sample size.

HPCs: 4; SLIP-HPCs: 0.

\section{Scolopsis bilineata (Bloch, 1793)}

Isop: Gnat: Praniza larvae (gills) [0]

Dige: Monr: Allobacciger macrorchis (intestine) [0]

(NGR)(NHR)

Dige: Opec: Allopodocotyle sp. (digestive tract) [0]

Nema: Cama: unidentified larvae (intestine) [0]

Hiru: Pisc: Trachelobdella sp. immature (gills) [0]

Remarks: 12 specimens examined ( 8 for gills, 9 for abdominal organs)

HPCs: 5; SLIP-HPCs: 1.

\section{Scolopsis taenioptera (Cuvier, 1830) *}

Nema: Anis: unidentified larvae (abdominal cavity) [0]

Remarks: 3 specimens examined ( 2 for gills, 3 for abdominal organs). * Fish species not kept for final parasite counts (Table 3 ) because of low sample size.

HPCs: 1; SLIP-HPCs: 0.

\section{Appendix 2. Parasite-host list}

8 fish species with low sample size * were included in Table 1 but not kept in final calculations of parasite numbers (Table 3 ).

\section{Isopoda}

Minimized number of taxa: 5

Number of SLIPs: total 4; Lutjanidae: reef: $1-0^{*}$, deep-sea: 3-3*, all: 4-3*; Nemipteridae: 0 .

Number of non-SLIP taxa: 0

Undistinguishable larval taxa: 1 (gnathiids)

Aegi: Aega musorstom

Pristipomoides filamentosus (NHR)

Cora: Argathona macronema

Lutjanus monostigma * (NHR)

Cymo: Anilocra gigantea

Etelis carbunculus

Etelis coruscans (NHR) 
Pristipomoides filamentosus (NHR)

Cymo: Anilocra longicauda

Pristipomoides argyrogrammicus (NHR)(NGR)

Gnat: Praniza larvae

Lutjanus argentimaculatus

Lutjanus russellii

Nemipterus furcosus

Pentapodus aureofasciatus

Pristipomoides auricilla *

Scolopsis bilineata

\section{Copepoda}

Minimized number of taxa: 14

Number of SLIPs: total 6; Lutjanidae: reef: 4-2*; deep-sea:

2-2*, all: 6-4*; Nemipteridae: 0-0*.

Undistinguishable larval taxa: 2

Note: for minimizing number of taxa, we considered

that the caligid and pennellid larvae could correspond

to their adult counterparts found on same or similar fish.

Cali: Caligus brevis

Etelis carbunculus (NHR)

Etelis coruscans (NHR)

Cali: Caligus n. sp. 2

Macolor niger *

Cali: chalimus larvae

Etelis carbunculus

Etelis coruscans

Lutjanus fulviflamma

Lutjanus vitta

Diss: Dissonus excavatus

Macolor niger *

Hats: Hatschekia clava

Lutjanus gibbus * (NHR)

Hats: Hatschekia n. sp. 17

Pentapodus aureofasciatus

Hats: Hatschekia n. sp. 18

Macolor niger *

Hats: Hatschekia n. sp. 19

Lutjanus kasmira

Hats: Hatschekia n. sp. 20

Lutjanus argentimaculatus

Hats: Hatschekia n. sp. 21

Etelis carbunculus

Etelis coruscans

Hats: Hatschekia tanysoma

Lutjanus fulviflamma (NGR)

Lerp: Clavellotis sp.

Pristipomoides argyrogrammicus

Lerp: Parabrachiella lutiani

Lutjanus argentimaculatus (NHR)

Lerp: Parabrachiella sp. 2

Etelis carbunculus
Penn: chalimus larvae and premetamorphic adults

Etelis coruscans

Penn: Lernaeolophus sultanus

Pristipomoides filamentosus (NHR)

\section{Monopisthocotylea}

Minimized number of taxa: 23

Number of SLIPs: total 11; Lutjanidae: reef: 8-8*, deep-sea: 2-2*, all: 10-10*; Nemipteridae: 1-1*.

Number of non-SLIP taxa: 10

Undistinguishable larval taxa: 0

Note: Note: for minimizing number of taxa,

Euryhaliotrema spp. and Ancyrocephalids Gen. spp. were each counted as one species (but this is certainly an underestimate), and the two unidentified capsalids and Diplectanum sp. were not counted (because they could, respectively, correspond to their better identified counterparts).

Ancy: Euryhaliotrema sp. (several spp.)

Lutjanus argentimaculatus

Lutjanus fulviflamma

Lutjanus fulvus *

Lutjanus quinquelineatus

Lutjanus russellii

Lutjanus vitta

Ancy: Haliotrematoides lanx

Lutjanus quinquelineatus

Ancy: Haliotrematoides longitubocirrus

Lutjanus fulvus *

Lutjanus quinquelineatus

Lutjanus russellii

Lutjanus vitta

Ancy: Haliotrematoides novaecaledoniae

Lutjanus argentimaculatus

Ancy: Haliotrematoides patellacirrus

Lutjanus fulviflamma

Lutjanus fulvus *

Lutjanus quinquelineatus

Lutjanus russellii

Lutjanus vitta

Ancy: Haliotrematoides potens

Lutjanus argentimaculatus

Ancy: Haliotrematoides tainophallus

Lutjanus fulviflamma

Ancy: unidentified sp. (often several sp.)

Lutjanus fulvus *

Lutjanus gibbus *

Lutjanus kasmira

Lutjanus quinquelineatus

Lutjanus rivulatus *

Lutjanus vitta

Pentapodus aureofasciatus 
Caps: Benedenia elongata Etelis carbunculus (NHR)(NGR)

Etelis coruscans (NHR)(NGR)

Pristipomoides argyrogrammicus (NHR)(NGR)

Caps: Capsalidae sp. 6

Lutjanus russellii

Caps: Capsalidae sp. 7

Lutjanus vitta

Caps: Capsalidae sp. 13

Nemipterus furcosus

Caps: Capsalidae sp. 17

Pristipomoides argyrogrammicus

Caps: Lagenivaginopseudobenedenia etelis Etelis coruscans (NHR)(NGR)

Caps: Metabenedeniella sp. Lutjanus argentimaculatus

Caps: Pseudonitzschia uku Aprion virescens

Caps: Trilobiodiscus lutiani Lutjanus argentimaculatus (NGR)

Caps: unidentified species Macolor niger * Nemipterus furcosus

Dipl: Calydiscoides limae Pentapodus aureofasciatus

Dipl: Diplectanum cf. curvivagina Pristipomoides argyrogrammicus

Dipl: Diplectanum cf. fusiforme Lutjanus kasmira Lutjanus vitta

Dipl: Diplectanum cf. opakapaka Pristipomoides auricilla *

Dipl: Diplectanum cf. spirale Lutjanus kasmira

Dipl: Diplectanum sp. Pristipomoides filamentosus

Gyro: unidentified species Macolor niger *

\section{Polyopisthocotylea}

Minimized number of taxa: 2

Number of SLIPs: 0

Number of non-SLIP taxa: 1

Undistinguishable larval taxa: 0

Note: for minimizing number of taxa, we considered all unidentified records as a single species.

Micr: Allomicrocotyla sp.

Etelis coruscans

Micr: unidentified species Nemipterus furcosus

Pentapodus aureofasciatus

unidentified family: unidentified species
Lutjanus fulviflamma

Lutjanus russellii

\section{Digenea}

Minimized number of taxa: 33

Number of SLIPs: total 20; Lutjanidae: reef: 10-10*, deep-sea: 5-4*, all 15-14*; Nemipteridae: 5-5*.

Number of non-SLIP taxa: 2

Undistinguishable larval taxa: 1 (didymozoid juveniles) Note: for minimizing number of taxa, we considered that the single non-SLIP taxon was Siphoderina cf. onaga; the 2 Siphoderina sp. from deep-sea and coral lutjanids were counted as 2 taxa; unidentified adult didymozoids and unidentified juveniles were counted each as 1 taxon.

Acan: Pleorchis uku Aprion virescens

Acan: Stephanostomum uku Aprion virescens

Cryp: Adlardia novaecaledoniae

Nemipterus furcosus

Cryp: Euryakaina manilensis

Lutjanus vitta

Cryp: Euryakaina marina

Lutjanus fulviflamma

Cryp: Metadena rooseveltiae

Pristipomoides argyrogrammicus (NHR)(NGR)

Cryp: Retrovarium manteri

Lutjanus argentimaculatus (NGR)

Cryp: Retrovarium saccatum

Lutjanus argentimaculatus (NHR)

Cryp: Siphoderina cf. onaga

Etelis coruscans

Cryp: Siphoderina hirastricta

Lutjanus argentimaculatus

Cryp: Siphoderina n. sp.

Etelis coruscans

Pristipomoides argyrogrammicus

Cryp: Siphoderina sp.

Lutjanus kasmira

Cryp: Siphoderina ulaula

Etelis carbunculus(NGR)

Pristipomoides argyrogrammicus (NHR)(NGR)

Cryp: Varialvus charadrus

Lutjanus quinquelineatus

Lutjanus vitta

Didy: unidentified adults

Etelis carbunculus

Pristipomoides filamentosus

Didy: unidentified juveniles

Lutjanus kasmira

Lutjanus russellii

Lutjanus vitta 
Nemipterus furcosus

Pristipomoides filamentosus

Fell: Tergestia magna

Etelis coruscans (NHR)(NGR)

Hemi: Ectenurus trachuri

Nemipterus furcosus (NHR)(NGR)

Hemi: Lecithochirium sp.

Caesio cuning

Lutjanus kasmira

Lutjanus vitta

Macolor niger *

Pentapodus nagasakiensis *

Pentapodus aureofasciatus

Hemi: Lecithocladium sp.

Pentapodus aureofasciatus

Leci: Aponurus sp.

Caesio cuning

Lepo: Lepidapedoides kalikali

Pristipomoides auricilla * (NGR)

Monr: Allobacciger macrorchis

Scolopsis bilineata

(NHR)(NGR)

Opec: Allopodocotyle sp.

Scolopsis bilineata

Opec: Hamacreadium mutabile

Lutjanus adetii

Lutjanus argentimaculatus (NHR)

Lutjanus fulviflamma

Lutjanus kasmira

Lutjanus quinquelineatus

Lutjanus russellii

Lutjanus vitta (NHR)

Opec: Macvicaria jagannathi

Nemipterus furcosus

Opec: Macvicaria sp.

Pentapodus nagasakiensis *

Opec: Neochoanostoma sp.

Pentapodus aureofasciatus

Opec: Neolebouria blatta

Etelis carbunculus

Pristipomoides argyrogrammicus

Opec: Neolebouria lineatus

Nemipterus furcosus

Opec: Neolebouria sp.

Pentapodus aureofasciatus

Scle: Prosogonotrema bilabiatum

Lutjanus adetii (NGR)

Tran: Transversotrema borboleta

Lutjanus kasmira (NGR)

\section{Bothriocephalidea}

Minimized number of taxa: 1

Number of SLIPs: 0
Number of non-SLIP taxa: 0

Undistinguishable larval taxa: 1

unidentified family: unidentified species, larvae

Caesio cuning

Lutjanus adetii

Lutjanus kasmira

Nemipterus furcosus

\section{Tetraphyllidea}

Minimized number of taxa: 1

Number of SLIPs: 0

Number of non-SLIP taxa: 0

Undistinguishable larval taxa: 1

unidentified family: unidentified species, larvae

Caesio cuning

Etelis carbunculus

Lutjanus argentimaculatus

Lutjanus kasmira

Lutjanus quinquelineatus

Lutjanus vitta

Nemipterus furcosus

Pentapodus aureofasciatus

Pentapodus nagasakiensis *

Pristipomoides argyrogrammicus

Pristipomoides auricilla *

\section{Trypanorhyncha}

Minimized number of taxa: 8

Number of SLIPs: 7

Number of SLIPs: total 7; Lutjanidae: reef: 2-2*, deep-

sea: 0-0*, all 2-2*; Nemipteridae: 6-6*.

Number of non-SLIP taxa: 0

Undistinguishable larval taxa: 1

Note: for minimizing number of taxa, we considered that all unproductive cysts from deep-sea lutjanids corresponded to 1 taxon and was distinct from the four other cyst-producing species.

Laci: Callitetrarhynchus gracilis, larvae Lutjanus vitta Nemipterus furcosus (NHR)

Laci: Floriceps minacanthus, larvae Nemipterus furcosus

Laci: Pseudolacistorhynchus heroniensis, larvae Lutjanus vitta (NHR)

Otob: Otobothrium mugilis, larvae Nemipterus furcosus (NHR)(NGR)

Tent: Nybelinia goreensis, larvae Nemipterus furcosus 
Tentaculariidae: Nybelinia indica, larvae Nemipterus furcosus (NHR)(NGR)

Tentaculariidae: Nybelinia queenslandensis, larvae Nemipterus furcosus (NHR)(NGR)

unidentified family: unidentified species, larvae

Etelis carbunculus

Etelis coruscans

Pristipomoides argyrogrammicus

Pristipomoides auricilla *

\section{Nematoda}

Minimized number of taxa: 17

Number of SLIPs: total 9; Lutjanidae: reef: 2-2*, deepsea: 4-4*, all 6-6"; Nemipteridae: 3-3*.

Number of non-SLIP taxa: 6

Undistinguishable larval taxa: 1 (anisakids, gnathostomatids)

Note: for minimizing number of taxa, we considered that unidentified anisakids corresponded to one of the 3 identified larval anisakid genera; Camallanus sp. and unidentified camallanids were counted as a single species; Huffmanela sp. was distinguished as different; the Raphidascaris (Ichthyascaris) sp. from reef lutjanids was different from that from deep-sea.

Anis: Anisakis sp., larvae

Nemipterus furcosus

Anis: Hysterothylacium sp., larvae

Nemipterus furcosus

Anis: Raphidascaris (Ichthyascaris) etelidis

Etelis coruscans

Pristipomoides filamentosus

Anis: Raphidascaris (Ichthyascaris) nemipteri

Nemipterus furcosus

Anis: Raphidascaris (Ichthyascaris) sp.

Etelis carbunculus

Lutjanus vitta

Anis: Terranova sp., larvae

Lutjanus vitta

Anis: unidentified species, larvae

Lutjanus adetii

Lutjanus fulviflamma

Lutjanus kasmira

Lutjanus quinquelineatus

Lutjanus rivulatus *

Pentapodus aureofasciatus

Pentapodus nagasakiensis *

Pristipomoides argyrogrammicus

Pristipomoides auricilla*

Scolopsis taenioptera *

Cama: Camallanus carangis

Nemipterus furcosus
Cama: Camallanus sp.

Pristipomoides filamentosus

Cama: unidentified species

Lutjanus vitta

Pristipomoides auricilla *

Scolopsis bilineata

Capi: Pseudocapillaria novaecaledoniensis

Pristipomoides argyrogrammicus

Cucu: Cucullanus bourdini

Pristipomoides auricilla *

Pristipomoides filamentosus

Cucu: Dichelyne etelidis

Etelis carbunculus

Etelis coruscans

Gnto: unidentified species

Nemipterus furcosus

Phil: Philometra brevicollis

Lutjanus vitta

Phil: Philometra mira

Lutjanus vitta

Phys: unidentified species

Nemipterus furcosus

Tric: Huffmanela branchialis

Nemipterus furcosus

Tric: Huffmanela sp.

Pentapodus aureofasciatus

\section{Hirudinea}

Minimized number of taxa: 1

Number of SLIPs: 0

Number of non-SLIP taxa: 1

Undistinguishable larval taxa: 0

Pisc: Trachelobdella sp., juvenile

Lutjanus rivulatus *

Scolopsis bilineata

\section{Turbellaria}

Minimized number of taxa: 1

Number of SLIPs: 0

Number of non-SLIP taxa: 1

Undistinguishable larval taxa: 0

unidentified family: unidentified species Nemipterus furcosus

\section{Acanthocephala}

Minimized number of taxa: 1

Number of SLIPs: 0

Number of non-SLIP taxa: 1

Undistinguishable larval taxa: 0 
unidentified family: unidentified species

Etelis carbunculus

\section{Appendix 3. Material deposited \\ Pisces}

Nemipterus furcosus, MNHN 2005-0768, 2006-1330.

Pentapodus aureofasciatus, MNHN 2004-1168, 20041169, 2004-2164, 2004-2172.

\section{Isopoda}

Aegi: Aega musorstom ex Pr. filamentosus, MNHN Is6295, Is6296, Is6297, Is6298.

Cora: Argathona macronema ex Lu. monostigma, MNHN Is6299.

Cymo: Anilocra gigantea ex Et. carbunculus, MNHNIU-2009-1710, IU-2009-1712; ex Et. coruscans, MNHN Is6293, MNHN-IU-2009-1711; ex Pr. filamentosus, MNHN Is6292.

Cymo: Anilocra longicauda ex Pr. argyrogrammicus, MNHN Is6294.

\section{Copepoda}

Cali: Caligus brevis, ex Et. coruscans, MNHN Cp8059, BMNH 2010.767-769; ex Et. carbunculus, BMNH 2010.770-771.

Diss: Dissonus excavatus, ex Ma. niger, MNHN Cp2436, BMNH 2007.316-325.

Hats: Hatschekia clava, ex Lu. gibbus, MNHN Cp8067. Hats: Hatschekia tanysoma, ex Lu. fulviflamma, MNHN Cp8068-8069.

Penn: Lernaeolophus sultanus, ex Pr. filamentosus, BMNH 2010.750.

Lerp: Parabrachiella lutiani, ex Lu. argentimaculatus, MNHN Cp8060, BMNH 2010.786-791.

\section{Monogenea}

Ancy: Haliotrematoides lanx ex Lu. quinquelineatus, slides MNHN JNC1590, JNC2145, JNC2140, USNPC 101344-5, BMNH 2008.11.19.36-37.

Ancy: Haliotrematoides longitubocirrus ex Lu. vitta, slides MNHN JNC2306, USNPC 101349, 101350-352, BMNH 2008.11.19.38-39; ex Lu. russellii, MNHN JNC1584, USNPC 101347; ex. Lu. fulvus, USNPC 101346; ex. Lu. quinquelineatus, MNHN JNC1588, USNPC 101348.

Ancy: Haliotrematoides novaecaledoniae ex $L u$. argentimaculatus, slides MNHN JNC2332, USNPC 101337, BMNH 2008.11.19.24-27.

Ancy: Haliotrematoides patellacirrus ex Lu. russellii, slides MNHN JNC1582, JNC1583, JNC1584, JNC1585,
USNPC 101338, BMNH 2008.11.19.28-29; ex Lu. fulviflamma, slide MNHN JNC2531; ex Lu. fulvus, slides MNHN JNC1591, JNC1592, USNPC 101341, BMNH 2008.11.19.32-33; ex Lu. quinquelineatus, slides MNHN JNC2146, JNC2147, JNC2142, JNC2141, JNC2144, USNPC 101342, 101343, BMNH 2008.11.19.34-35; ex. Lu. vitta, MNHN 2470. Ancy: Haliotrematoides potens ex Lu. argentimaculatus, slides MNHN JNC2332, USNPC 101336, BMNH 2008.11.19.23.

Ancy: Haliotrematoides tainophallus ex Lu. fulviflamma, slides MNHN JNC2531.

Caps: Benedenia elongata ex gills Et. carbunculus (fish JNC2459) SAMA AHC 35066 (6 slides). Caps: Benedenia elongata ex gills Et. coruscans (fish JNC2448) MNHN JNC2448 A1 (1 slide). Caps: Benedenia elongata ex gills Pr. argyrogrammicus (from fish JNC2449) MNHN JNC2449 B1 (1 slide), (from fish JNC2603) MNHN JNC2603 A3 (1 slide), SAMA AHC 35067 (2 slides), (from fish JNC2604) MNHN JNC2604 A1 (1 slide), (from fish JNC2729) AHC 35068 (1 slide of a single specimen that was 'slivered'; sliver fixed in 95\% ethanol; possibly conspecific with Capsalidae sp. 17 of Perkins 2010), (from fish JNC2730) SAMA AHC 35069 (1 slide). Caps: Capsalidae sp. 7 (see Perkins 2010) ex branchiostegal membranes $\mathrm{Lu}$. vitta (from fish JNC2686) SAMA AHC 29706 (1 slide). Caps: Lagenivaginopseudobenedenia etelis ex gills Et. coruscans (from fish JNC2616) MNHN JNC2616 A1 (1 slide), JN111, JN115, JN119.

Caps: Metabenedeniella sp. (see Perkins 2010) ex pectoral fins $\mathrm{Lu}$. argentimaculatus (from fish JNC2735) SAMA AHC 29714 (3 slides).

Caps: Pseudonitzschia uku (see Perkins et al. 2009) ex gills Aprion virescens (from fish JNC1557) MNHN JNC1557 A1 (1 slide), SAMA AHC 35070 (2 slides). Caps: Trilobiodiscus lutiani (see Perkins 2010) ex gills Lu. argentimaculatus (from JNC2332), USNPC 101526 (4 slides), (from JNC2735) SAMA AHC 29713 (1 slide). Caps: Capsalidae sp. 13 (see Perkins 2010) ex branchiostegal membranes Ne. furcosus (from fish JNC2692) SAMA AHC 29707 (2 slides), AHC 35073 (4 slides).

Caps: Capsalidae sp. 13 of Perkins (2010) ex gills Ne. furcosus (from fish JNC971) MNHN JNC971A6 (1 slide), SAMA AHC 35071 (2 slides), (from fish JNC2692) SAMA AHC 35072 (5 slides), (from fish JNC2693) SAMA AHC 35075 (4 slides), (from fish JNC2694) SAMA AHC 35076 (6 slides), (from fish JNC2695) SAMA AHC 35077 (2 slides).

Caps: Capsalidae sp. 13 of Perkins (2010) ex pelvic and anal fins Ne. furcosus (from fish JNC2694), SAMA AHC 35074 (3 slides). 
Dipl: Diplectanum cf. curvivagina ex Pr. argyrogrammicus, slides MHNH JNC2426, JNC2449, JNC2456, JNC2729, JNC2996.

Dipl: Diplectanum cf. opakapaka ex Pr. auricilla, slides MHNH JNC2457.

Dipl: Diplectanum sp. ex Pr. filamentosus, slides MHNH JNC2452, JNC2460.

\section{Polyopisthocotylea}

Micr: Allomicrocotyla sp. ex. Et. coruscans, slides JN114.

Unidentified polyopisthocotylean ex $L u$. russellii, slide JNC1582.

\section{Digenea}

Acan: Pleorchis uku ex Aprion virescens, MNHN JNC2568.

Acan: Stephanostomum uku ex Ap. virescens, MNHN JNC1557C.

Cryp: Adlardia novaecaledoniae ex Ne. furcosus, MNHN JNC2291-1, 16, MNHN JNC2289-1-5, MNHN JNC2291-2-4, MNHN JNC2331B-1-4, MNHN JNC2288-1-3, MNHN JNC2398-1, 10; BMNH 2008.12.30.1-3.

Cryp: Euryakaina manilensis ex Lu. vitta, MNHN JNC2285, MNHN JNC2286, MNHN JNC2306, MNHN JNC2470, MNHN JNC2686, MNHN JNC2862, MNHN JNC2887, MNHN JNC2897, MNHN JNC2898, MNHN JNC2900, MNHN JNC2902; BMHN 2010.4.23.1-12.

Cryp: Euryakaina marina ex Lu. fulviflamma, MNHN JNC1269B.

Cryp: Retrovarium manteri ex Lu. argentimaculatus, MNHN JNC 2735-2, BMNH 2012.2.15.7

Cryp: Retrovarium saccatum ex Lu. argentimaculatus, MNHN JNC 2735-3

Cryp: Siphoderina hirastricta ex Lu. argentimaculatus, MNHN JNC 2735-1

Cryp: Varialvus charadrus ex Lu. quinquelineatus, MNHN JNC2143; ex Lu. vitta MNHN JNC2285, MNHN JNC2688, MNHN JNC2689.

Fell: Tergestia magna ex Et. coruscans, MNHN JNC 2616B-1, JNC2617B-1; ex Pr. argyrogrammicus, MNHN JNC2820B-1.

Hemi: Ectenurus trachuri ex Ne. furcosus, MNHN JNC2586-1.

Lepo: Lepidapedoides kalikali ex Pr. auricilla, MNHN JNC2457-1, JNC2468-1, BMNH 2012.2.15.6.

Monr: Allobacciger macrorchis ex Sc. bilineata, MNHN JNC2522-1, BMNH 2012.2.15.16.

Opec: Hamacreadium mutabile ex Lu. adetii, MNHN JNC3021-1; ex Lu. argentimaculatus, MNHN
JNC2735-2, BMNH 2012.2.15.15; ex Lu. fulviflamma, MNHN JNC2531-1, BMNH 2012.2.15.13; ex Lu. kasmira, MNHN JNC2708-1-2, BMNH 2012.2.15.14; ex Lu. quinquelineatus, MNHN JNC 2142-1; ex Lu. russellii, MNHN JNC2191-1; ex Lu. vitta, MNHN JNC 2285-1, MNHN 2306-1, MNHN JNC2470-1, MNHN JNC2686-1, MNHN JNC2900-1, MNHN JNC2896-1, MNHN JNC2898-1, MNHN JNC2899-1, BMNH 2012.2.15.9-12.

Opec: Macvicaria jagannathi ex Ne. furcosus, MNHN JNC2331A-1-3, JNC2366A-1., BMNH 2009.2.12.11-14.

Opec: Neolebouria blatta ex Et. carbunculus, MNHN JNC2427; ex Pr. argyrogrammicus, MNHN JNC2464-1, MNHN JNC2426, MNHN JNC2456, MNHN

JNC2461, MNHN JNC2464-66, MNHN JNC2604-05, MNHN JNC 2729, MNHN JNC2995-1, MNHN JNC2996A-1; BMNH 2009.4.7.1-7, 2012.2.15.8.

Opec: Neolebouria lineatus ex Ne. furcosus, MNHN JNC2398-1-2; BMNH 2009.2.12.15.

Scle: Prosogonotrema bilabiatum ex Lu. adetii, MNHN JNC3022-1.

Tran: Transversotrema borboleta ex Lu. kasmira, MNHN JNC2708.

\section{Trypanorhyncha}

Laci: Callitetrarhynchus gracilis ex Ne. furcosus, slide MNHN JNC2596.

Laci: Floriceps minacanthus ex Ne. furcosus, slide MNHN JNC3019.

Otob: Otobothrium mugilis ex Ne. furcosus, slides MNHN JNC2610, JNC2586.

Tent: Nybelinia goreensis ex Ne. furcosus, slide MNHN JNC2612.

Tent: Nybelinia indica ex Ne. furcosus, slides MNHN JNC2288, JNC2611, JNC3016.

\section{Nematoda}

Anis: Raphidascaris (Ichthyascaris) etelidis ex Et. coruscans, MNHN JNC2616, JNC2617, JNC2623, HCIP N-969; ex Pr. filamentosus, MNHN JNC2460.

Anis: Raphidascaris (Ichthyascaris) nemipteri ex Ne. furcosus, MNHN JNC218, JNC330, JNC214, JNC217, JNC278, JNC311, HCIP N-836.

Cama: Camallanus carangis ex Ne. furcosus, MNHN JNC276, JNC280, JNC465, JNC467, JNC1261, HCIP N-859.

Capi: Pseudocapillaria novaecaledoniensis ex Pr. argyrogrammicus, MNHN JNC2604, HCIP N-930.

Cucu: Cucullanus bourdini ex Pr. auricilla MNHN JNC2457, ex Pr. filamentosus JNC2460, HCIP N-949. 


\author{
Cucu: Dichelyne etelidis ex Et. carbunculus, MNHN \\ JNC2459, HCIP N-948; ex Et. coruscans, MNHN \\ JNC2617. \\ Phil: Philometra brevicollis ex Lu. vitta, MNHN \\ JNC2901, JNC2038, HCIP N-967. \\ Phil: Philometra mira ex Lu. vitta, MNHN JNC2901, \\ HCIP N-968. \\ Tric: Huffmanela branchialis ex Ne. furcosus, NHN \\ JNC216, HCIP N-816, BMNH 2004.2.18.1, SAMA \\ AHC 32856. \\ Tric: Huffmanela sp. ex Pe. aureofasciatus, MNHN \\ JNC1040.
}

\begin{abstract}
Abbreviations
NGR: New geographic record; NHR: New host record; HPC: Host-parasite combination; SLIP: Species-level identified parasite; SLIP-HPC: Species-level identified parasite - host-parasite combination.

Institutional abbreviations

BMNH: Natural History Museum, London, United Kingdom; HCIP: Helminthological Collection, Institute of Parasitology, Biology Centre, Academy of Sciences of the Czech Republic, České Budějovice, Czech Republic; MNHN: Muséum National d'Histoire Naturelle, Paris, France; SAMA AHC: South Australian Museum Adelaide, Australian Helminthological Collection, Adelaide, Australia; USNPC: United States National Parasite Collection, Beltsville, USA.

\section{Abbreviations for higher parasite taxa}

The following abbreviations are used in Tables and Appendices.: For all: Unid: Unidentified family; Isop: Isopoda; Families: Aegi: Aegidae; Cora: Corallanidae; Cymo: Cymothoidae; Gnat: Gnathiidae; Cope: Copepoda; Families: Cali: Caligidae; Diss: Dissonidae; Hats: Hatschekiidae; Lerp: Lernaeopodidae; Penn: Pennellidae; Mono: Monogenea; Monop: Monopisthocotylea; Poly: Polyopisthocotylea; Families: Ancy: Ancyrocephalidae; Caps: Capsalidae; Dipl: Diplectanidae; Gyro: Gyrodactylidae; Micr: Microcotylidae; Dige: Digenea; Families: Acan: Acanthocolpidae; Cryp: Cryptogonimidae; Didy: Didymozoidae; Fell: Fellodistomatidae; Hemi: Hemiuridae; Leci: Lecithasteridae; Lepo: Lepocreadiidae; Monr: Monorchiidae; Opec: Opecoelidae; Scler: Sclerodistomidae; Tran: Transversotrematidae; Tryp: Cestoda Trypanorhyncha; Families: Laci: Lacistorhynchidae; Otob: Otobothriidae; Tent: Tentaculariidae; Both: Cestoda Bothriocephalidea (no family identified); Tetr: Cestoda Tetraphyllidea (no family identified); Nema: Nematoda; Families: Anis: Anisakidae; Cama: Camallanidae; Capi: Capillariidae; Cucu: Cucullanidae; Gnto: Gnathostomatidae; Phil: Philometridae; Phys: Physalopteridae; Tric: Trichosomoididae; Hiru: Hirudinea (no family identified); Family: Pisc: Piscicolidae; Turb: 'Turbellaria'; Acantho: Acanthocephala (no family identified).
\end{abstract}

\section{Competing interests}

The authors declare that they have no competing interests.

\section{Authors' contributions}

$J \sqcup J$ collected fish and parasites and compiled and compared results. $J J I B$ GAB RAB TLM FM JPT IDW identified parasites. GAB JLJ made figures. JLJ IB GAB RAB TLM FM JPT IDW wrote the paper. Authors are in alphabetical order, except $\lrcorner\lrcorner$. All authors read and approved the final manuscript.

\section{Authors' information}

$J \sqcup$ : specialist of phylogeny and taxonomy of parasitic worms, mainly monogeneans; professor and curator of the collections of parasitic worms of MNHN, Paris, France, has spent more than eight years (2003-2011) in Nouméa, New Caledonia, South Pacific, collecting and studying parasites from fish; UMR 7138 Systématique, Adaptation, Évolution, Muséum National d'Histoire Naturelle, Case postale 51, 55, rue Buffon, 75231 Paris cedex 05, France.

IB: specialist of phylogeny and taxonomy of parasitic worms, including trypanorhynch cestodes; Department of Veterinary Science, University of Melbourne, Veterinary Clinical Centre, Werribee 3030, Victoria, Australia.
GAB: specialist of all aspects of biology and taxonomy of copepods, including parasitic groups; Department of Zoology, Natural History Museum, Cromwell Road, London SW7 5BD, UK.

RAB: specialist of phylogeny and taxonomy of parasitic worms, mainly digeneans and cestodes; Department of Zoology, Natural History Museum, Cromwell Road, London SW7 5BD, UK.

TLM: specialist of phylogeny and taxonomy of digeneans, especially cryptogonimids; Biodiversity Program, Queensland Museum, PO Box 3300, South Brisbane, Queensland, 4101 Australia

FM: specialist of biology and taxonomy of parasitic nematodes; Institute of Parasitology, Biology Centre, Academy of Sciences of the Czech Republic, Branišovská 31, 37005 České Budějovice, Czech Republic.

JPT: specialist of taxonomy and biogeography of parasitic isopods; Équipe Adaptation écophysiologique et Ontogenèse, UMR 5119 (CNRS-UM2-IRDUM1-IFREMER), Université Montpellier 2, Place Eugène Bataillon, 34095 Montpellier cedex 05, France.

IDW: specialist of biology, taxonomy and phylogeny of monogeneans, including capsalids; Monogenean Research Laboratory, The South Australian Museum, Adelaide 5000, \& Marine Parasitology Laboratory, \& Australian Centre for Evolutionary Biology and Biodiversity, The University of Adelaide, North Terrace, Adelaide 5005, South Australia, Australia.

\section{Acknowledgements}

Numerous students helped for the parasitological survey. The identification of certain hosts was kindly confirmed (from photographs) by John E. Randall (Bishop Museum, Hawaii) or Ronald Fricke (Staatliches Museum für Naturkunde, Stuttgart, Germany). Parasite identifications were kindly provided by E. Burreson, L. Euzet, D. C. Kritsky and S. Shamsi.

Partly supported (FM) by the Czech Science Foundation (grant no. P505/12/G112), and research project of the Institute of Parasitology BC AS CR (Z60220518). Partly supported (IDW) by Australian Research Council grant no. DP0556780 (2005-07) awarded to IDW and Steve Donnellan (South Australian Museum) which permitted IDW to visit Nouméa for 3 weeks in October-November 2008 ably assisted by Drs Lizzie Perkins and Vanessa Glennon who were supported by a J.D. Smyth Travel Award from the Australian Society for Parasitology Inc. awarded to Dr Lizzie Perkins. Partly supported $(J\lrcorner)$ by ATM barcode (MNHN) and ATM Biodiversité actuelle et fossile (MNHN).

\section{Author details}

1UMR 7138 Systématique, Adaptation, Évolution, Muséum National d'Histoire Naturelle, Case postale 51, 55, rue Buffon, 75231 Paris cedex 05, France. ${ }^{2}$ Department of Veterinary Science, University of Melbourne, Veterinary Clinical Centre, Werribee 3030, Victoria, Australia. ${ }^{3}$ Department of Zoology, Natural History Museum, Cromwell Road, London SW7 5BD, UK. ${ }^{4}$ Biodiversity Program, Queensland Museum, PO Box 3300, South Brisbane, Queensland 4101, Australia. Institute of Parasitology, Biology Centre, Academy of Sciences of the Czech Republic, Branišovská 31370 05, České Budějovice, Czech Republic. ${ }^{6}$ Équipe Adaptation écophysiologique et Ontogenèse, UMR 5119 (CNRS-UM2-IRD-UM1-IFREMER), Université Montpellier 2, Place Eugène Bataillon, 34095 Montpellier cedex 05, France. ${ }^{7}$ Monogenean Research Laboratory, The South Australian Museum, Adelaide 5000, \& Marine Parasitology Laboratory, \& Australian Centre for Evolutionary Biology and Biodiversity, The University of Adelaide, North Terrace, Adelaide 5005, South Australia, Australia.

Received: 27 April 2012 Accepted: 7 July 2012

Published: 4 September 2012

\section{References}

1. Reaka-Kudla ML: The global biodiversity of coral reefs: a comparison with rain forests. In Biodiversity II: Understanding and protecting our biological resources. Edited by Reaka-Kudla ML, Wilson DE. E.O. W. Washington: Joseph Henry Press; 1997:83-108.

2. Rohde K: Marine parasitology in Australia. Search (Sydney) 1976, 7:477-482.

3. Rohde K: Species diversity of parasites on the Great Barrier Reef. Z ParasitenKde 1976, 50:93-94.

4. Cribb TH, Bray RA, Barker SC, Adlard RD, Anderson GR: Ecology and diversity of digenean trematodes of reef and inshore fishes of Queensland. Int J Parasitol 1994, 24:851-860. 
5. Whittington ID: Diversity "down under": monogeneans in the Antipodes (Australia) with a prediction of monogenean biodiversity worldwide. Int J Parasitol 1998, 28:1481-1493.

6. Justine J-L: Parasites of coral reef fish: how much do we know? With a bibliography of fish parasites in New Caledonia. Belg J Zool 2010, 140:155-190. Suppl.

7. Justine J-L, Beveridge I, Boxshall GA, Bray RA, Moravec F, Trilles J-P, Whittington ID: An annotated list of parasites (Isopoda, Copepoda, Monogenea, Digenea, Cestoda and Nematoda) collected in groupers (Serranidae, Epinephelinae) in New Caledonia emphasizes parasite biodiversity in coral reef fish. Folia Parasitol 2010, 57:237-262.

8. Justine J-L, Beveridge I, Boxshall GA, Bray RA, Moravec F, Whittington ID: An annotated list of fish parasites (Copepoda, Monogenea, Digenea, Cestoda and Nematoda) collected from Emperors and Emperor Bream (Lethrinidae) in New Caledonia further highlights parasite biodiversity estimates on coral reef fish. Zootaxa 2010, 2691:1-40.

9. Allen GR: FAO species catalogue. Vol. 6. Snappers of the world. An annotated and illustrated catalogue of lutjanid species known to date. FAO Fisheries Synopsis 125. Rome: FAO; 1985.

10. Carpenter KE: FAO species catalogue. Vol 8. Fusilier fishes of the world. An annotated and illustrated catalogue of caesionid species known to date. FAO Fisheries Synopsis 125. Rome: FAO; 1988.

11. Russell BC: FAO Species catalogue. Vol. 12. Nemipterid Fishes of the World. (Threadfin breams, whiptail breams, monocle breams, dwarf monocle breams, and coral breams). Family Nemipteridae. An annotated and illustrated catalogue of nemipterid species known to date. FAO Fisheries Synopsis 125 Rome: FAO; 1990.

12. Miller TL, Cribb TH: Phylogenetic relationships of some common Indo-Pacific snappers (Perciformes: Lutjanidae) based on mitochondrial DNA sequences, with comments on the taxonomic position of the Caesioninae. Mol Phylogenet Evol 2007, 44:450-460.

13. Gold JR, Voelker G, Renshaw MA: Phylogenetic relationships of tropical western Atlantic snappers in subfamily Lutjaninae (Lutjanidae: Perciformes) inferred from mitochondrial DNA sequences. Biol J Linn SoC 2011, 102:915-929.

14. Guo Y, Wang Z, Liu C, Liu L, Liu Y: Phylogenetic relationships of South China Sea snappers (Genus Lutjanus; Family Lutjanidae) based on mitochondrial DNA sequences. Mar Biotechnol 2007, 9:682-688.

15. Guo Y, Wong Z, Liu C, Liu Y: Sequencing and analysis of the complete mitochondrial DNA of Russell's snapper (L. russellii). Progr Nat Sci 2008, 18:1233-1238

16. Eschmeyer WN, Fong JD: Pisces. In Animal biodiversity: An outline of higherlevel classification and survey of taxonomic richness, Zootaxa, Volume 3148. Edited by Zhang Z-Q.; 2011:27-38.

17. Fricke R, Kulbicki M, Wantiez L: Checklist of the fishes of New Caledonia, and their distribution in the Southwest Pacific Ocean (Pisces). Stuttg Beitr Natkd Ser A (Biol) 2011, 4:341-463.

18. Kulbicki M, Bozec Y-M, Labrosse P, Letourneur Y, Mou-Tham G, Wantiez L: Diet composition of carnivorous fishes from coral reef lagoons of New Caledonia. Aquat Living Resour 2005, 18:231-250.

19. Fourmanoir P: Pêche profonde en Nouvelle-Calédonie et aux Loyauté. Nouméa: Commission du Pacifique Sud / South Pacific Commission (CPS/SPC); 1977:8. www.spc.int.

20. Marie AD, Justine J-L: Monocotylids (Monogenea: Monopisthocotylea) from Aetobatus cf. narinari off New Caledonia, with a description of Decacotyle elpora n. sp. Syst Parasitol 2005, 60:175-185.

21. Justine J-L, Dupoux C, Cribb TH: Resolution of the discrepant hostspecificity of Pseudorhabdosynochus species (Monogenea, Diplectanidae) from serranid fishes in the tropical Indo-Pacific. Acta Parasitol 2009, 54:119-130.

22. Justine J-L, Briand MJ: Three new species, Lamellodiscus tubulicornis n. sp., L. magnicornis n. sp. and L. parvicornis n. sp. (Monogenea: Diplectanidae) from Gymnocranius spp. (Lethrinidae: Monotaxinae) off New Caledonia, with proposal of the new morphological group 'tubulicornis' within Lamellodiscus Johnston \& Tiegs, 1922. Syst Parasitol 2010, 75:159-179.

23. Schoelinck C, Cruaud C, Justine J-L: Are all species of Pseudorhabdosynochus strictly host specific? - a molecular study. Parasitol Int 2012, 61:356-359.

24. Justine J-L: Three new species of Huffmanela Moravec, 1987 (Nematoda: Trichosomoididae) from the gills of marine fish off New Caledonia. Syst Parasitol 2004, 59:29-37.
25. Justine J-L: Huffmanela spp. (Nematoda, Trichosomoididae) parasites in coral reef fishes off New Caledonia, with descriptions of $H$. balista n. sp. and H. longa n. sp. Zootaxa 2007, 1628:23-41.

26. Trilles JP: Sur quatre Isopodes Cymothoïdés du Pacifique (Nouvelle Calédonie). Cahiers ORSTOM, série Océan 1972, 10:3-17.

27. Bruce NL, Harrison-Nelson EB: New records of fish parasitic marine isopod crustaceans (Cymothoidae, subfamily Anilocrinae) from the Indo-west Pacific. Proc Biol Soc Wash 1988, 101:585-602.

28. Herklots J: Deux nouveaux genres de Crustacés vivant en parasites sur des poissons, Epichthyes et Ichthyoxenos. Arch Néerl Sci Ex Nat 1870, 5:120-137.

29. Schiøedte JC, Meinert FW: Symbolae ad Monographiam Cymothoarum Crustaceorum Isopodum Familiae 2. Anilocridae. Naturhistorisk Tidsskrift 1881, 13(3):1-166.

30. Trilles J-P: Les Cymothoidae (Crustacea, Isopoda) du Monde (Prodrome pour une Faune). Stud Mar 1994, 21/22:5-288

31. Bruce NL: Australian Pleopodias Richardson, 1910, and Anilocra Leach, 1818 (Isopoda: Cymothoidae), crustacean parasites of marine fishes. Rec Aust Mus 1987, 39:85-130.

32. Bruce NL: Reassessment of the isopod crustacean Aega deshaysiana (Milne Edwards, 1840) (Cymothoida: Aegidae): a world-wide complex of 21 species. Zool J Linn Soc 2004, 142:135-222.

33. Delaney M: Phylogeny and Biogeography of the Marine Isopod Family Corallanidae (Crustacea, Isopoda, Flabellifera). Contr Sci 1989, 409:1-75.

34. Smit NJ, Basson L: Gnathia pantherina sp. n. (Crustacea: Isopoda: Gnathiidae), a temporary ectoparasite of some elasmobranch species from southern Africa. Folia Parasitol 2002, 49:137-151.

35. Smit NJ, Basson L, Van As JG: Life cycle of the temporary fish parasite, Gnathia africana (Crustacea: Isopoda: Gnathiidae). Folia Parasitol 2003, 50:135-142.

36. J-s H, Kim I-H: New species of Hatschekia Poche, 1902 (Copepoda: Hatschekiidae) parasitic on marine fishes of Kuwait. Syst Parasitol 2001 49:73-79.

37. Kabata Z: Copepoda parasitic on Australian fishes, XIII - Family Hatschekiidae. J Nat Hist 1991, 25:91-121.

38. Boxshall GA, Halsey SH: An introduction to copepod diversity. London: Ray Society; 2004.

39. Raibaut A, Combes C, Benoit F: Analysis of the parasitic copepod species richness among Mediterranean fish. J Mar Syst 1998, 15:185-206.

40. Shiino SM: Note on a new parasitic copepod Caligus brevis n. sp. Bull Jpn Soc Sci Fish 1954, 20:178-183.

41. Hewitt GC: Some New Zealand parasitic Copepoda of the Family Caligidae. Trans R Soc New Zeal Zool 1963, 4:61-115.

42. Ho J-S, Lin C-L: Sea Lice of Taiwan (Copepoda: Siphonostomatoida: Caligidae). Keelung: The Sueichan Press; 2004.

43. Kritsky DC, Bullard SA, Bakenhaster MD: First report of gastrocotylinean post-oncomiracidia (Platyhelminthes: Monogenoidea: Heteronchoinea) on gills of flyingfish (Exocoetidae), snapper (Lutjanidae), dolphinfish (Coryphaenidae), and amberjack (Carangidae) from the Gulf of Mexico: Decoy hosts and the dilution effect. Parasitol Int 2011, 60:274-282.

44. Lester RJG, Sewell KB: Checklist of parasites from Heron Island, Great Barrier Reef. Aust J Zool 1989, 37:101-128.

45. Kritsky DC, Yang T, Sun Y: Dactylogyrids (Monogenoidea, Polyonchoinea) parasitizing the gills of snappers (Perciformes, Lutjanidae): Proposal of Haliotrematoides $\mathrm{n}$. gen. and descriptions of new and previously described species from marine fishes of the Red Sea, the eastern and Indo-west Pacific Ocean, Gulf of Mexico and Caribbean Sea. Zootaxa 1970, 2009:1-51

46. Fajer-Avila EJ, Velasquez-Medina SP, Betancourt-Lozano M: Effectiveness of treatments against eggs, and adults of Haliotrema $\mathrm{sp}$ and Euryhaliotrema sp (Monogenea: Ancyrocephalinae) infecting red snapper, Lutjanus guttatus. Aquaculture 2007, 264:66-72.

47. Justine J-L: Species of Calydiscoides Young, 1969 (Monogenea: Diplectanidae) from lethrinid fishes, with the redescription of all of the type-specimens and the description of C. euzeti n. sp. from Lethrinus rubrioperculatus and L. xanthochilus off New Caledonia. Syst Parasitol 2007, 67:187-209.

48. Lim LHS: Species of Calydiscoides Young, 1969 (Monogenea; Diplectanidae Bychowsky, 1957; Lamellodiscinae Oliver, 1969) from nemipterid fishes off Peninsular Malaysia. Syst Parasitol 2003, 55:115-126. 
49. Yamaguti S: Monogenetic Trematodes of Hawaiian Fishes. Honolulu: University of Hawaii Press; 1968.

50. Kent ML, Heidel JR, Marie A, Moriwake A, Moriwake V, Alexander B, Watral V, Kelley CD: Diseases of Opakapaka Pristipomoides filamentosus. Fish Health Section. In Diseases in Asian Aquaculture V. Edited by Walker P, Lester R, Bondad-Reantaso MG. Manila: Asian Fisheries Society; 2005:183-195.

51. Oliver G, Paperna I: Diplectanidae Bychowsky, 1957 (Monogenea, Monopisthocotylea), parasites de Perciformes de Méditerranée orientale, de la mer Rouge et de l'océan Indien. Bull Mus Natl Hist Nat, Paris 1984, 4(6, section A):49-65.

52. Vignon M, Morat F, Galzin R, Sasal P: Evidence for spatial limitation of the bluestripe snapper Lutjanus kasmira in French Polynesia from parasite and otolith shape analysis. J Fish Biol 2008, 73:2305-2320.

53. Vignon M, Sasal P, Rigby MC, Galzin R: Multiple parasite introduction and host management plan: case study of lutjanid fish in the Hawaiian Archipelago. Dis Aquat Org 2009, 85:133-145.

54. Nagibina LF: New species of the genus Diplectanum (Monogenoidea, Diplectanidae). In: Fauna, systematics and phylogeny of Monogenoidea. Tr Biologo-Pochvennogo Inst, Nov Ser 1976, 35:89-96.

55. Deveney MR, Whittington ID: Three new species of Benedenia Diesing, 1858 from the Great Barrier Reef, Australia with a key to species of the genus. Zootaxa 2010, 2348:1-22.

56. Whittington ID: Revision of Benedeniella Johnston, 1929 (Monogenea: Capsalidae), its assignment to Entobdellinae Bychowsky, 1957 and comments on subfamilial composition. Zootaxa 2010, 2519:1-30.

57. Whittington ID, Deveney MR: New Benedenia species (Monogenea: Capsalidae) from Diagramma labiosum (Perciformes: Haemulidae) on the Great Barrier Reef, Australia, with oncomiracidial descriptions and a report of egg attachment to the host. J Parasitol 2011, 97:1026-1034.

58. Perkins EM, Donnellan SC, Bertozzi T, Chisholm LA, Whittington ID: Looks can deceive: Molecular phylogeny of a family of flatworm ectoparasites (Monogenea: Capsalidae) does not reflect current morphological classification. Mol Phylogenet Evol 2009, 52:705-714.

59. Perkins EM: Family ties: molecular phylogenetics, evolution and radiation of flatworm parasites (Monogenea: Capsalidae). PhD, The University of Adelaide; 2010.

60. Whittington ID: The Capsalidae (Monogenea: Monopisthocotylea): a review of diversity, classification and phylogeny with a note about species complexes. Folia Parasitol 2004, 51:109-122.

61. Whittington ID: Benedeniine capsalid monogeneans from Australian fishes: Pathogenic species, site-specificity and camouflage. $J$ Helminthol 1996, 70:177-184.

62. Whittington ID, Deveney MR, Wyborn SJ: A revision of Benedenia Diesing, 1858 including a redescription of $B$. sciaenae (van Beneden, 1856) Odhner, 1905 and recognition of Menziesia Gibson, 1976 (Monogenea: Capsalidae). J Nat Hist 1856, 2001(35):663-777.

63. Whittington ID, Ernst I: Migration, site-specificity and development of Benedenia lutjani (Monogenea: Capsalidae) on the surface of its host, Lutjanus carponotatus (Pisces: Lutjanidae). Parasitology 2002, 124:423-434.

64. Horton MA, Whittington ID: A new species of Metabenedeniella (Monogenea, Capsalidae) from the dorsal fin of Diagramma pictum (Perciformes, Haemulidae) from the Great Barrier Reef, Australia with a revision of the genus. J Parasitol 1994, 80:998-1007.

65. In FishBase. World Wide Web electronic publication. Edited by Froese R, Pauly D.; 2012. www.fishbase.org.

66. Yamaguti S: New monogenetic trematodes from Hawaiian fishes, II. Pac Sci 1966, 20:419-434

67. Bychowsky BE, Nagibina L: New Capsalidae (Monogenoidea) from Pacific fishes. Parazitologiya 1967, 1:521-528

68. Grutter AS: Spatial and temporal variations of the ectoparasites of seven reef fish species from Lizard Island and Heron Island, Australia. Mar Ecol Prog Ser 1994, 115:21-30

69. Cribb TH, Bray RA, Olson PD, Littlewood DTJ: Life cycle evolution in the Digenea: a new perspective from phylogeny. Adv Parasitol 2003, 54:197-254.

70. Gibson DI, Bray RA: The Hemiuridae (Digenea) of fishes from the northeast Atlantic. Bull Br Mus (Nat Hist) (Zoo/ Ser) 1986, 51:1-125.

71. Miller TL, Bray RA, Goiran C, Justine J-L, Cribb TH: Adlardia novaecaledoniae n.g., n. sp. (Digenea: Cryptogonimidae) from the fork-tailed threadfin bream Nemipterus furcosus (Val.) (Perciformes: Nemipteridae) off New Caledonia. Syst Parasitol 2009, 73:151-160
72. Velasquez CC: Cryptogonimidae (Digenea: Trematoda) from Philippine food fishes. J Parasitol 1961, 47:914-918.

73. Manter HW: Studies in the digenetic trematodes of fishes of Fiji. III. Families Acanthocolpidae, Fellodistomatidae, and Cryptogonimidae. J Parasitol 1963, 49:443-450.

74. Yamaguti S: Digenetic trematodes of Hawaiian fishes. Tokyo: Keigaku; 1970.

75. Gu C-D, Shen J-W: Digenetic trematodes of fishes from the Xisha Islands, Guangdong Province, China. I. Stud Mar Sin 1983, 20:157-184. In Chinese.

76. Miller TL, Cribb TH: Coevolution of Retrovarium n. gen. (Digenea: Cryptogonimidae) in Lutjanidae and Haemulidae (Perciformes) in the Indo-West Pacific. Int J Parasitol 2007, 37:1023-1045.

77. Hafeezullah M, Siddiqi AH: Digenetic trematodes of marine fishes of India. Part I. Bucephalidae and Cryptogonimidae. Indian J Helminthol 1970, 22:1-22.

78. Miller TL, Adlard RD, Bray RA, Justine J-L, Cribb TH: Cryptic species of Euryakaina n. g. (Digenea: Cryptogonimidae) from sympatric lutjanids in the Indo-West Pacific. Syst Parasitol 2010, 77:185-204.

79. Miller TL, Bray RA, Justine J-L, Cribb TH: Varialvus gen. nov. (Digenea, Cryptogonimidae), from species of Lutjanidae (Perciformes) off the Great Barrier Reef, New Caledonia and the Maldives. Acta Parasitol 2010, 55:327-339.

80. Bray RA, Webster BL, Bartoli P, Littlewood DTJ: Relationships within the Acanthocolpidae Lühe, 1906 and their place among the Digenea. Acta Parasitol 2005, 50:281-291.

81. Bray RA, Justine J-L: Acanthocolpidae (Digenea) of marine fishes off New Caledonia, with the descriptions of two new species. Folia Parasitol 2011, 58:35-47.

82. Bray RA, Cribb TH: Digeneans of the family Opecoelidae Ozaki, 1925 from the southern Great Barrier Reef, including a new genus and three new species. J Nat Hist 1989, 23:429-473.

83. McCoy OR: The life-history of a marine trematode, Hamacreadium mutabile Linton, 1910. Parasitology 1929, 21:220-225.

84. Gupta PC, Singh RB: Four new digenetic trematodes from marine fishes off Puri coast, Bay of Bengal. Indian J Parasitol 1985, 9:25-34.

85. Gupta PC, Gupta VC: On three opecoelid trematodes (Digenea) from marine fishes, Bay of Bengal, India. Proc Parasitol 1988, 6:59-68.

86. Aken'ova TOL, Cribb TH: Two new species of Neolebouria Gibson, 1976 (Digenea: Opecoelidae) from temperate marine fishes of Australia. Syst Parasitol 2001, 49:65-71.

87. Bray RA, Justine J-L: Neolebouria blatta n. sp. (Digenea: Opecoelidae) from Pristipomoides argyrogrammicus (Valenciennes) and Etelis carbunculus Cuvier (Perciformes: Lutjanidae) off New Caledonia. Syst Parasitol 2009, 74:161-167

88. Bray RA, Justine J-L: Opecoelids (Platyhelminthes: Digenea) from the forktailed threadfin bream Nemipterus furcosus (Valenciennes, 1830) (Perciformes: Nemipteridae), with preliminary keys to the problematic genera Macvicaria Gibson \& Bray, 1982 and Neolebouria Gibson, 1976. Acta Parasitol 2009, 54:218-229.

89. Hunter JA, Cribb TH: A cryptic complex of species related to Transversotrema licinum Manter, 1970 from fishes of the Indo-West Pacific, including descriptions of ten new species of Transversotrema Witenberg, 1944 (Digenea: Transversotrematidae). Zootaxa 2012, 3176:1-44.

90. Cribb TH, Pichelin S, Dufour V, Bray RA, Chauvet C, Faliex E, Galzin R, Lo CM, Lo-Yat A, Morand $S$, et al: Parasites of recruiting coral reef fish larvae in New Caledonia. Int J Parasitol 2000, 30:1445-1451.

91. Pozdnyakov SE, Gibson DI: Family Didymozoidae Monticelli, 1888. In Keys to the Trematoda, Volume 3. Edited by Bray RA, Gibson DI, Jones A. London: CAB International and The Natural History Museum; 2008:631-734.

92. Bray RA: Hemiuridae (Digenea) from marine fishes of the southern Indian Ocean: Dinurinae, Elytrophallinae, Glomericirrinae and Plerurinae. Syst Parasitol 1990, 17:183-217.

93. Nasir P: Monotypic status of Prosogonotrema Perez Vigueras, 1940 (Trematoda: Digenea). Riv Parassitol 1973, 34:271-276.

94. Nahhas FM, Sey O, Nishimoto R: Digenetic trematodes of marine fishes from the Kuwaiti Coast of the Arabian Gulf: Families Pleorchiidae, Fellodistomidae, and Cryptogonimidae, with a description of two new species, Neoparacryptogonimus sphericus and Paracryptogonimus ramadani. J Helminthol Soc Wash 1998, 65:129-140.

95. Machida M: Monorchiidae (Trematoda, Digenea) from fishes of Japanese and adjacent waters. Bull Natl Sci Mus, Tokyo Ser A Zool 2005, 31:123-136. 
96. Kuramochi T: Digenean trematodes of fishes caught in Sagami Bay, off Izu Islands and off Ogasawara Islands. Mem Natl Mus Nat Sci, Tokyo 2011, 47:51-63.

97. Korotaeva VD: New species of Trematoda of the genus Tergestia Stossich, 1899 (Trematoda, Fellodistomatidae). Izv Tikhookean Nauchno-Issled Inst Rybn Khoz Okeanogr 1972, 81:263-266.

98. Olson PD, Caira JN, Jensen K, Overstreet RM, Palm HW, Beveridge I: Evolution of the trypanorhynch tapeworms: Parasite phylogeny supports independent lineages of sharks and rays. Int J Parasitol 2010, 40:223-242.

99. Palm HW: The Trypanorhyncha Diesing, 1863. Bogor: PKSPL-IPB Press; 2004.

100. Andrews AH, Kalish JM, Newman SJ, Johnston JM: Bomb radiocarbon dating of three important reef-fish species using Indo-Pacific $\Delta^{14} \mathrm{C}$ chronologies. Mar Freshw Res 2011, 62:1259-1269.

101. Moravec F: Dracunculoid and anguillicoloid nematodes parasitic in vertebrates. Praha: Academia; 2006

102. Santos Cavalcanti ET, Takemoto RM, Alves LC, Chellappa S: First record of endoparasite Philometra sp. (Nematoda: Philometridae) in lane snapper Lutjanus synagris from the coast of Rio Grande do Norte, Brazil. Mar Biodiv Rec 2011, 3:e93.

103. Justine J-L: Huffmanela plectropomi n. sp. (Nematoda: Trichosomoididae: Huffmanelinae) from the coralgrouper Plectropomus leopardus (Lacépède) off New Caledonia. Syst Parasitol 2011, 79:139-143.

104. Bosques Rodríguez LJ: Metazoan parasites of snappers, Lutjanidae (Pisces) from Puerto Rico. PhD thesis, University of Puerto Rico; 2004.

105. Bullard SA, Barse AM, Curran SS, Morris JA: First record of a digenean from invasive Lionfish, Pterois cf. volitans, (Scorpaeniformes: Scorpaenidae) in the Northwestern Atlantic Ocean. J Parasitol 2011, 97:833-837.

106. Cannon LRG, Lester RJG: Two turbellarians parasitic in fish. Dis Aquat Org 1988, 5:15-22.

107. Justine J-L, Leblanc $P$, Keller F, Lester RJG: Turbellarian black spot disease in bluespine unicornfish Naso unicornis in New Caledonia caused by the parasitic turbellarian Piscinquilinus sp. Dis Aquat Org 2009, 85:245-249.

108. Foata J, Quilichini Y, Justine J-L, Bray RA, Marchand B: Ultrastructural study of spermiogenesis and the spermatozoon of Cavisoma magnum (Southwell, 1927) (Acanthocephala, Palaeacanthocephala, Cavisomidae), from Siganus lineatus (Pisces, Teleostei, Siganidae) (Valenciennes, 1835) in New Caledonia. Micron 2012, 43:141-149.

109. Rohde K: Gill Monogenea of deepwater and surface fish in southeastern Australia. Hydrobiologia 1988, 160:271-283.

110. Boxshall GA: Host specificity in copepod parasites of deep-sea fishes. J Mar Syst 1998, 15:215-223.

111. Bray RA, Littlewood DTJ, Herniou EA, Williams B, Henderson RE: Digenean parasites of deep-sea teleosts: a review and case studies of intrageneric phylogenies. Parasitology 1999, 119:S125-S144.

112. Klimpel S, Busch MW, Kellermans E, Kleinertz, Palm HW: Metazoan deep-sea fish parasites. Acta Biol Benrodis Supplbd 2009, 11:1-384.

113. Kulbicki M, Guillemot N, Amand M: A general approach to length-weight relationships for New Caledonian lagoon fishes. Cybium 2005, 29:235-253.

114. Poulin R, Morand S: Parasite Biodiversity. Washington: Smithsonian Books; 2004.

115. Luque $J$, Poulin R: Metazoan parasite species richness in Neotropical fishes: hotspots and the geography of biodiversity. Parasitology 2007, 134:865-878.

116. McNamara MKA, Adlard RD, Bray RA, Sasal P, Cribb TH: Monorchiids (Platyhelminthes: Digenea) of chaetodontid fishes (Perciformes): Biogeographical patterns in the tropical Indo-West Pacific. Parasitol Int 2012, 61:288-306.

117. McNamara MKA, Cribb TH: Taxonomy, host specificity and dietary implications of Hurleytrematoides (Digenea: Monorchiidae) from chaetodontid fishes on the Great Barrier Reef. Parasitol Int 2011, 60:255-269

118. Gunter NL, Adlard RD: Seven new species of Ceratomyxa Thélohan, 1892 (Myxozoa) from the gall-bladders of serranid fishes from the Grear Barrier Reef, Australia. Syst Parasitol 2009, 73:1-11.

119. Gunter NL, Whipps CM, Adlard RD: Ceratomyxa (Myxozoa: Bivalvulida): Robust taxon or genus of convenience? Int J Parasitol 2009, 39:1395-1405.

120. Beveridge I, Justine J-L: Two new species of Prochristianella Dollfus, 1946 (Platyhelminthes, Cestoda) from the blue-spotted stingray, Neotrygon kuhlii (Müller \& Henle, 1841) off New Caledonia. Zoosystema 2010, 32:643-652.
121. Bray RA, Cribb TH, Justine J-L: Multitestis Manter 1931 (Digenea: Lepocreadiidae) in ephippid and chaetodontid fishes (Perciformes) in the south-western Pacific Ocean and the Indian Ocean off Western Australia. Zootaxa 2010, 2427:36-46.

122. Bray RA, Cribb TH, Justine J-L: Diploproctodaeum spp. (Digenea: Lepocreadiidae) in Australian and New Caledonian waters including two new species from Tetraodontiformes and new records of related species. Acta Parasitol 2010, 51:313-326.

123. Bray RA, Justine J-L: Bucephaline digeneans (Bucephalidae) in Sphyraena putnamae Jordan \& Seale (Sphyraenidae) from the lagoon off New Caledonia. Syst Parasitol 2011, 79:123-138.

124. Moravec F, Justine J-L: Two new genera and species of cystidicolids (Nematoda, Cystidicolidae) from marine fishes off New Caledonia. Parasitol Int 2010, 59:198-205.

125. Stork NE, Lyal CHC: Extinction or "co-extinction" rates. Nature 1993, 366:307-307.

126. Koh LP, Dunn RR, Sodhi NS, Colwell RK, Proctor HC, Smith VS: Species coextinctions and the biodiversity crisis. Science 2004, 305:1632-1634.

127. Windsor DA: Equal rights for parasites. Conserv Biol 1995, 9:1-2.

128. Windsor DA: Most of species on Earth are parasites. Int J Parasitol 1998, 28:1939-1941.

129. Dunn RR, Harris NC, Colwell RK, Koh LP, Sodhi NS: The sixth mass coextinction: are most endangered species parasites and mutualists? Proc Roy Soc B Biol Sci 2009, 276:3037-3045.

130. Dobson A, Lafferty KD, Kuris AM, Hechinger RF, Jetz W: Homage to Linnaeus: How many parasites? How many hosts? Proc Natl Acad Sci US A 2008, 105:11482-11489.

131. Rózsa L: Endangered parasite species. Int J Parasito/ 1992, 22:265-266.

132. Justine J-L: Parasite biodiversity in a coral reef fish: twelve species of monogeneans on the gills of the grouper Epinephelus maculatus (Perciformes: Serranidae) off New Caledonia, with a description of eight new species of Pseudorhabdosynochus (Monogenea: Diplectanidae). Syst Parasitol 2007, 66:81-129.

133. Moir ML, Vesk PA, Brennan KEC, Keith DA, Hughes L, McCarthy MA: Current constraints and future directions in estimating coextinction. Conserv Biol 2010, 24:682-690.

134. Mihalca A, Gherman C, Cozma V: Coendangered hard-ticks: threatened or threatening? Parasites Vectors 2011, 4:71.

135. Cardoso P, Erwin TL, Borges PAV, New TR: The seven impediments in invertebrate conservation and how to overcome them. Biol Conserv 2011, 144:2647-2655.

136. Hughes TP: Catastrophes, phase shifts, and large-scale degradation of a Caribbean coral reef. Science 1994, 265:1547-1551.

137. Roberts CM, McClean CJ, Veron JEN, Hawkins JP, Allen GR, McAllister DE, Mittermeier CG, Schueler FW, Spalding M, Wells F, et al: Marine biodiversity hotspots and conservation priorities for tropical reefs. Science 2002, 295:1280-1284.

138. Pandolfi JM, Bradbury RH, Sala E, Hughes TP, Bjorndal KA, Cooke RG, McArdle D, McClenachan L, Newman MJH, Paredes G, et al: Global trajectories of the long-term decline of coral reef ecosystems. Science 2003, 301:955-958.

139. Jones GP, McCormick MI, Srinivasan M, Eagle JV: Coral decline threatens fish biodiversity in marine reserves. Proc Natl Acad Sci U S A 2004, 101:8251-8253.

140. Bruno JF, Selig ER: Regional decline of coral cover in the Indo-Pacific: Timing, extent, and subregional comparisons. PLOS ONE 2007, 2:e711.

141. Pascal M, Richer de Forges B, Le Guyader H, Simberloff D: Mining and other threats to the New Caledonia biodiversity hotspot. Conserv Biol 2008, 22:498-499.

142. Richer de Forges B, Pascal M: La Nouvelle-Calédonie, un "point chaud" de la biodiversité mondiale gravement menacé par l'exploitation minière. J Soc Oceanistes 2008, 126-127:95-112.

143. Cribb TH, Bray RA: Gut wash, body soak, blender, and heat-fixation: approaches to the effective collection, fixation and preservation of trematodes of fishes. Syst Parasitol 2010, 76:1-7.

144. Justine J-L, Briand MJ, Bray RA: A quick and simple method, usable in the field, for collecting parasites in suitable condition for both morphological and molecular studies. Parasitol Res 2012, 111:341-351.

145. Khalil LF, Jones A, Bray RA: Keys to the Cestode Parasites of Vertebrates. Wallingford: CAB International; 1994 
146. Kuchta R, Scholz T, Brabec J, Bray RA: Suppression of the tapeworm order Pseudophyllidea (Platyhelminthes: Eucestoda) and the proposal of two new orders, Bothriocephalidea and Diphyllobothriidea. Int J Parasitol 2008, 38:49-55.

147. Healy CJ, Caira JN, Jensen K, Webster BL, Littlewood DTJ: Proposal for a new tapeworm order, Rhinebothriidea. Int J Parasitol 2009, 39:497-511.

148. Jovelin $\mathrm{R}$, Justine J-L: Phylogenetic relationships within the polyopisthocotylean monogeneans (Platyhelminthes) inferred from partial 28 S rDNA sequences. Int J Parasitol 2001, 31:393-401.

149. Justine J-L: Non-monophyly of the monogeneans? Int J Parasitol 1998, 28:1653-1657.

150. Mollaret I, Jamieson BGM, Adlard RD, Hugall A, Lecointre G, Chombard C, Justine J-L: Phylogenetic analysis of the Monogenea and their relationships with Digenea and Eucestoda inferred from $28 \mathrm{~S}$ rDNA sequences. Mol Biochem Parasitol 1997, 90:433-438.

151. Mollaret I, Jamieson BGM, Justine J-L: Phylogeny of the Monopisthocotylea and Polyopisthocotylea (Platyhelminthes) inferred from $28 \mathrm{~S}$ rDNA sequences. Int J Parasitol 2000, 30:171-185.

152. Perkins EM, Donnellan SC, Bertozzi T, Whittington ID: Closing the mitochondrial circle on paraphyly of the Monogenea (Platyhelminthes) infers evolution in the diet of parasitic flatworms. Int J Parasitol 2010, 40:1237-1245

153. Lim LHS, Timofeeva TA, Gibson DI: Dactylogyridean monogeneans of the siluriform fishes of the Old World. Syst Parasitol 2001, 50:159-197.

154. Lim LHS, Justine J-L: Two new species of ancyrocephalid monogeneans from Lethrinus rubrioperculatus Sato (Perciformes: Lethrinidae) off New Caledonia, with the proposal of Lethrinitrema n. g. Syst Parasitol 2011, 78:123-128.

155. Boxshall GA, Lin C-L, Ho J-S, Ohtsuka S, Venmathi Maran BA, Justine J-L: A revision of the family Dissonidae Kurtz, 1924 (Copepoda: Siphonostomatoida). Syst Parasitol 2008, 70:81-106.

156. Justine J-L, Brena PF: Calydiscoides limae sp. nov. (Monogenea, Diplectanidae) from Pentapodus aureofasciatus (Perciformes, Nemipteridae) off New Caledonia. Acta Parasitol 2009, 54:22-27.

157. Moravec F, Justine J-L: Two anisakid nematodes from marine fishes off New Caledonia, including Raphidascaris (Ichthyascaris) nemipteri n. sp. from Nemipterus furcosus. Syst Parasitol 2005, 62:101-110.

158. Moravec F, Justine J-L: Some trichinelloid nematodes from marine fishes off New Caledonia, including description of Pseudocapillaria novaecaledoniensis sp. nov. (Capillariidae). Acta Parasitol 2010, 55:71-80.

159. Moravec F, Justine J-L: Cucullanid nematodes (Nematoda: Cucullanidae) from deep-sea marine fishes off New Caledonia, including Dichelyne etelidis n. sp. Syst Parasitol 2011, 78:95-108.

160. Moravec F, Justine J-L: Two new gonad-infecting Philometra species (Nematoda: Philometridae) from the marine fish Lutjanus vitta (Perciformes: Lutjanidae) off New Caledonia. Folia Parasitol 2011 58:302-310.

161. Moravec F, Justine J-L: Raphidascaris (Ichthyascaris) etelidis $\mathrm{n} . \mathrm{sp}$ (Nematoda, Anisakidae), a new ascaridoid nematode from lutjanid fishes off New Caledonia. Zoosystema 2012, 34:113-121.

162. Boxshall GA, Huys R: Copepoda of New Caledonia. In Compendium of Marine Species from New Caledonia (Vol Documents Scientifiques et Techniques II7, Deuxième Édition, pp 259-265). Edited by Payri CE, de Forges BR. Nouméa, New Caledonia: Institut de Recherche pour le Développement; 2007. $435 \mathrm{pp}+$ Color Plates.

163. Bray RA, Justine J-L: Pseudopycnadena tendu sp. nov. (Digenea, Opecoelidae) in the yellow-spotted triggerfish Pseudobalistes fuscus (Perciformes, Balistidae) and additional opecoelids parasitizing fishes from the waters off New Caledonia. Acta Parasitol 2007, 52:13-17.

164. Quilichini Y, Foata J, Justine J-L, Bray RA, Marchand B: Sperm ultrastructure of the digenean Siphoderina elongata (Platyhelminthes, Cryptogonimidae) intestinal parasite of Nemipterus furcosus (Pisces, Teleostei). Parasitol Res 2009, 105:87-95.

165. Moravec F, Justine J-L: Some philometrid nematodes (Philometridae), including four new species of Philometra, from marine fishes off New Caledonia. Acta Parasitol 2008, 53:369-381.

166. Moravec F, Justine J-L, Rigby MC: Some camallanid nematodes from marine perciform fishes off New Caledonia. Folia Parasito/ 2006, 53:223-239.

167. Bleeker P: Recherches sur les Crustacés de I'Inde Archipélagique II. Sur les Isopodes cymothoadiens de l'Archipel Indien. Verhand Natuurkunde Ver, Batavia 1857, 2:20-40.
168. Monod T: Tanaidacea et Isopoda. Mission Robert-Ph. Dollfus en Égypte. Mém Inst Égypte 1933, 21:161-264.

169. Milne Edwards H: Ordre des Copépodes. In Histoire naturelle des Crustacés comprenant l'anatomie, la physiologie et la classification de ces animaux. Volume 3; 1840:411-529.

170. Heller C: Crustaceen. Reise der Oesterreichischen Fregatte 'Novara' um die Erde 1865, 2(3):1-280.

171. Pillai NK: Description of some Brachiella and Clavellopsis with comments on Isobranchia Heegaard. Crustaceana 1968, (Supplement 1):119-135.

172. Shiino SM: Copepods parasitic on Japanese fishes. 5. Five species of the family Pandaridae. Rep Fac Fish, Pref Univ Mie 1954, 1:291-332.

173. Bychowsky BE, Nagibina LF: New and little known species of the genus Haliotrema Johnston et Tiegs, 1922 (Monogenoidea). 2. Zool Zh 1971, 50:25-40.

174. Egorova TP: A taxonomic review of the subfamily Benedeniinae (Monogenoidea: Capsalidae). Parazitologiya 1997, 438-451.

175. Yamaguti S: New monogenetic trematodes from Hawaiian fishes, I. Pac Sci 1965, 19:55-95

176. Bijukumar A: Digenetic trematode parasites of the flatfishes (Pleuronectiformes) of the Kerala coast, India. Acta Parasitol 1997, 42:149-157.

177. Linton E: Helminth fauna of the dry Tortugas II. Trematodes. Pap Tortugas Lab Carnegie Inst Washing 1910, 4:11-98.

178. Miller TL, Cribb TH: Family Cryptogonimidae Ward, 1917. In Keys to the Trematoda, Volume 3. Edited by Bray RA, Gibson DI, Jones A. Wallingford: CAB International; 2008:51-112.

179. Vigueras IP: Prosogonotremidae n. fam. y Prosogonotrema bilabiatum n. gen. n. sp. (Trematoda, Distomata) parasito de Ocyurus chrysurus Bloch (Pisces). Mem Soc Cubana Hist Nat 1940, 14:249-252.

180. Yamaguti S: Studies on the helminth fauna of Japan. Part 2. Trematodes of fishes, I. Jap J Zool 1934, 5:249-541.

181. Campbell RA, Beveridge I: Floriceps minacanthus sp. nov. (Cestoda: Trypanorhyncha) from Australian fishes. Trans R Soc S Aust 1987 111:189-194.

182. Chandra KJ: Nybelinia indica n. sp. (Cestoda: Trypanorhyncha) from teleost fishes off Waltair coast, Bay of Bengal. Riv Parassitol 1986, 3:199-202.

183. Dollfus RP: Sur une collection de Tétrarhynques homéacanthes de la famille des Tentaculariidae récoltés principalement dans la région de Dakar. Bull Inst Fond Afr Noire, Sér A 1960, 22:788-852.

184. Hiscock ID: A new species of Otobothrium (Cestoda, Trypanorhyncha) from Australian fish. Parasitology 1954, 44:65-70.

185. Jones MK, Beveridge I: Nybelinia queenslandensis sp. $n$. (Cestoda: Trypanorhyncha) parasitic in Carcharhinus melanopterus, from Australia, with observations on the fine structure of the scolex including the rhyncheal system. Folia Parasitol 1998, 45:295-311.

186. Pintner T: Wenigbekanntes und Unbekanntes von Rüssel-bandwürmern. II. Öster Akad Wissenschn Sitzunzber, Math Naturwissene Kla, Abt 11931 140:777-820.

187. Rudolphi CA: Entozoorum synopsis, cui accedunt mantissa duplex et indices locupletissimi. Berolini; 1819

188. Sakanari J: Grillotia heroniensis, sp. nov., and G. overstreeti, sp. nov., (Cestoda: Trypanorhyncha) from Great Barrier Reef fishes. Aust J Zool 1989, 37:81-87.

189. Olsen LS: Some nematodes parasitic in marine fishes. Publi Inst Mar SC Univ Texas 1952, 2:173-215.

190. Petter AJ, Le Bel J: Two new species in the genus Cucullanus (Nematoda - Cucullanidae) from the Australian Region. Mém Inst Oswaldo Cruz, Rio de Janeiro 1992, 87(suppl. I):201-206.

doi:10.1186/2046-9063-8-22

Cite this article as: Justine et al: An annotated list of fish parasites (Isopoda, Copepoda, Monogenea, Digenea, Cestoda, Nematoda) collected from Snappers and Bream (Lutjanidae, Nemipteridae, Caesionidae) in New Caledonia confirms high parasite biodiversity on coral reef fish. Aquatic Biosystems 2012 8:22. 